\title{
A model of energy management analysis, case study of a sugar factory in Turkey
}

\author{
TOLGA TANER $^{1, * \mathbb{D}}$, MECIT SIVRIOĞLU ${ }^{2}$, HÜSEYIN TOPAL $^{2}$, AHMET SELIM DALKıLıÇ $^{3}$ \\ and SOMCHAI WONGWISES ${ }^{4}$ \\ ${ }^{1}$ Department of Motor Vehicles and Transportation Technology, Vocational School of Technical Sciences, \\ Aksaray University, 68100 Aksaray, Turkey \\ ${ }^{2}$ Department of Mechanical Engineering, Gazi University, 06570 Maltepe, Ankara, Turkey \\ ${ }^{3}$ Heat and Thermodynamics Division, Department of Mechanical Engineering, Faculty of Mechanical \\ Engineering, Yildiz Technical University, 34349 Yildiz, Besiktas, Istanbul, Turkey \\ ${ }^{4}$ Fluid Mechanics, Thermal Engineering and Multiphase Flow Research Lab. (FUTURE), Department of \\ Mechanical Engineering, Faculty of Engineering, King Mongkut's University of Technology, Thonburi \\ (KMUTT), Bangmod, Bangkok 10140, Thailand \\ e-mail: tolgataner@aksaray.edu.tr
}

MS received 31 March 2017; revised 25 July 2017; accepted 3 August 2017; published online 19 March 2018

\begin{abstract}
This study presents a case study of energy management in a sugar factory in Turkey. The main idea of the study is to analyse energy consumption, the quantity of material production, and figure out a suitable energy efficiency for the case study of a sugar factory subsequently. Firstly, a material production and energy consumption audit were performed for the sugar factory. Secondly, energy efficiency was calculated from the energy data. The SPSS (Statistical Package for the Social Sciences) statistical software was used to ensure the accuracy of the data. The factory's energy consumption was calculated as 43,590.25 toe (tons of oil equivalent) over the last year. These results were used for CUSUM (Cumulative Sum Deviation Method) graphics. This research poses the consumption of energy, cost of energy and the relationship between energy usage and material production of sugar. The unit of energy cost was 688.22 [\$/toe] for the last year. This result showed that the factory decreased the unit of energy by optimisation. The results indicated that the investigated sugar factory should pay attention to the energy management issue in order to comply with the Energy Efficiency of Turkish Law and Directives.
\end{abstract}

Keywords. Energy management; CUSUM; consumption of energy; material production; SPSS statistical software; data accuracy.

\section{Introduction}

Energy management is an important issue for the Turkish food industry. The Turkish economy depends on sugar material production strongly, and the world's most important sugar factory is located in Turkey. A high quantity stream of energy that is important for a sugar factory should be managed in tandem.

In this study, it was posed a case study of energy management in a sugar factory in Turkey. The main idea of this study is to analyse energy consumption, the quantity of material production, and figure out a proper energy efficiency for the case study of a sugar factory respectively. Once, it was investigated a material production and energy consumption audit for the sugar factory. Then, energy data

*For correspondence was taken for the calculation of energy efficiency for the factory. The accuracy of the data was verified by using the SPSS (Statistical Package for the Social Sciences) statistical software.

Finding the results referred, as the sugar factory should watch out the energy management issue because of respect to the Energy Efficiency of Turkish Law and Directives. Sugar factories are very significant for the Turkish economy. In this study, Çumra Sugar Integrated Plant, which is one of the integrated facilities in the food sector of Turkey and the World, was chosen for the research of energy management. This study was supported by a Scientific Research (Date of work: February 2010 to January 2013) for the case of a sugar factory in Turkey.

Palensky and Dietrich [1] defined energy management as a means to optimise the energy system. They stated that industry and research groups have been working to 
optimise energy material production (energy generator) and energy dispensing in the factory for energy conservation.

Wang [2] described the phase of energy management as follows: After energy consumption data have been accumulated and analysed and the energy movement plan for energy savings has been recommended for the plant, an energy management program should be set up to implement the audit advice. The report should begin with an executive summary that provides the manager of the facility with a briefing of the total savings available and the highlights of each energy saving opportunity. The report can begin with an executive summary that provides a manager of the facility with a brief of the total savings available and the highlights of each energy saving opportunity. The report should describe the facility that has been audited and provide information on the operation of the facility that is related to energy costs. The energy costs can be analysed. Energy saving opportunities are recommended along with the analyses of the associated costs and benefits and the cost effectiveness [2].

Taner and Sivrioglu [3] indicated that sugar factories need more energy due to their product processing. Abdelaziz et al [4] clarified as energy is a vital factor for the economic competition capacity and employment. Petrecca [5] indicated that energy management should include four main sections. These sections are data of the production and energy consumption, audit of energy and accounting, analysis of energy (feasibility study for investment cost), and personnel training and information [5]. A strategy of appointment energy demand is an important issue for energy management. Throttling and optimizing energy using systems may result in procedures with a view to decrease energy demands per unit of output while maintaining or decreasing the total costs of material production output in the system $[4,5]$.

When energy values increased and indicated the upcoming depletion of world energy resources, energy management became a significant function of a management of the industrial in the 2000s. Taner [6] remarked that energy consumption must be analysed carefully and determined the energy efficiency of a production of food processes.

Nowadays, a role of the energy management has expanded into industry. Kannan and Boie [7] found that energy management is disadvantageous for monetary, social and ecological causes in all industries. The senior management of firms plan various energy management projects regularly. Many factories refer to their energy saving events specifically in their annual reports. In order to be successful, energy management should include 4 major parts as a historical data analysis, an audit of energy and cost, an engineering analysis of investments based on the recommendations of the feasibility study, engineering analysis of investments based on the recommendations of the feasibility study, and staff's training and their knowledge $[4,5,7]$.
Several previous studies performed in the energy management field. For instance, Giacone and Manco [8] focused on energy management to control the consumption and cost of energy. Bunsea et al [9] defined energy management as useful regarding a factory for economic, environmental and social reasons. Tanaka [10] measured energy efficiency performance (energy consumption) in his study. Gielen and Taylor [11] found that energy is a key production factor in many industries. Palamutcu [12] remarked that one of the greatest energy costs is electric energy for factories. Taner [13] showed that energy consumption was important for the calculation of energy management. It should be noted that the General Directorate of Renewable Energy [14] is an official organisation that helps Turkish factories with research into energy saving. Ramirez et al [15] conducted a cross-country consumption of energy analysis and analysis of energy efficiency for the dairy industry in four European countries. Ramirez et al [16] used energy and physical production data to develop energy efficiency indicators for the meat industry. Xu et al [17] studied energy usage in existing cheese markets and compared to the energy performance of individual plants and systems. Dörr et al [18] defined energy performance as energy efficiency, energy use and consumption. Zhang et al [19] surveyed an empirical relationship between economic development and consumption of energy by material production, nonmaterial production and households. The Department of Minerals and Energy Pretoria [20] defined energy management as an important component of an effective energy management strategy. Morvay and Gvozdenac [21] presented a model of efficient energy performance in the industrial plants. Beggs [22] included data analysis techniques that are generally used in the energy management programmes. The Sustainable Energy Authority of Ireland [23] indicated the importance of an energy manager in the energy management programme. The energy manager should not manipulate the energy and energy cost data [23]. Blatt [24] focused on the impact of energy efficiency on energy management. Turner and Doty [25] defined energy management as a significant role to support many factories.

In this study, energy management defines energy performance. Several similar studies have been performed. Chen et al [26] described energy management as the factor by which energy performance can vary. Reilly et al [27] investigated the energy performance of a building. Mavromatidis et al [28] presented diagnostic tools for the energy performance of supermarkets. Diaz et al [29] provided a comparison of the energy performance in buildings. Gul and Patidar [30] examined the optimum energy performance of a building. Granderson et al [31] described energy performance data as being important to national efforts to improve building efficiency.

A sugar factory was chosen for this study because of the importance of sugar factories in Turkey. It is a significant factory and is one of the integrated facilities in the food 


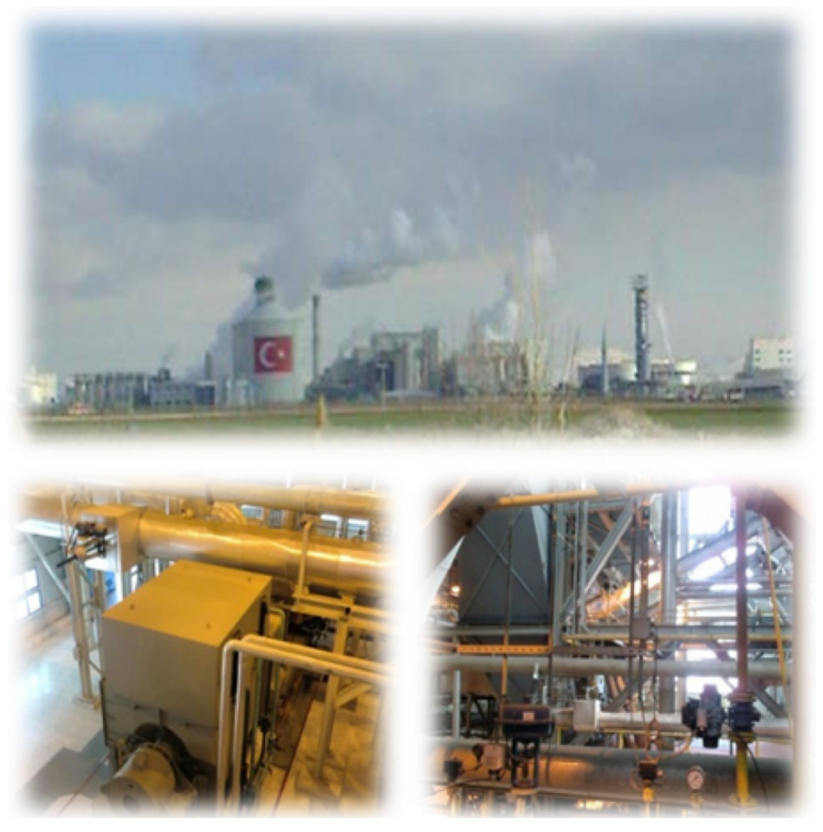

Figure 1. Detailed photos of the sugar factory.

sector of Turkey and the World. This study was supported by a Scientific Research (Date of work: February 2010 to January 2013) for the case of a sugar factory in Turkey. This study was carried out in Çumra Sugar Integrated Plant. The energy data were taken with permission from the factory administration having in collaboration with the Department of Factory Central Monitoring and Directorate of Maintenance and Energy. The investigated sugar factory is a liquid sugar plant, bioethanol plant and other sugar production plant. The annual production of crystal sugar is 280.000 tonnes, the annual production of cube sugar is 100,000 tonnes, the annual production of liquid sugar is 140,000 tonnes, the annual production of chocolate is 2,000 tonnes, the annual production of brown sugar is 2,160 tonnes, the annual production of bioethanol is $84,000,000$ litres, and the annual production of brown sugar is 2,160 tonnes. The beet processing capacity is 170 tonnes per day. The total investment cost of the sugar factory is $\$ 340,000,000$.

Detailed photos of the sugar factory are shown in figure 1. At the top of the photo is a general view of the factory. At the bottom of the left photo is power plant energy turbine. The bottom right photo is a fluidized bed boiler.

Previous similar studies also used SPSS (the Statistical Package for the Social Sciences) software for the analysis of the energy management data. In this study, data of energy consumption and production of the factory were controlled before any comparisons. These results were analysed in SPSS for the data's distribution.

Chen et al [26] performed statistical analysis of the parameters using the SPSS software. Chen et al [32] remarked that SPSS was one of the most popular software packages in statistics. Aranda et al [33] performed graphical and regression analysis by using Minitab and SPSS. Turhan et al [34] indicated a SPSS solution for evaluation, estimation and prediction, and developed regression models with good accuracy. Huebner et al [35] used the detailed results of the ANOVA (Analysis Of Variance) from the SPSS software. Orosa and Oliveira [36] also used the ANOVA method for their energy data. Choi et al [37] analysed their collected data via SPSS software. Kalayci [38] referred to SPSS in detail. Aksozen et al [39] exploited SPSS software for their energy consumption data. Farreny et al [40] conducted analysis with the aid of PASW (Predictive Analytics Software) Statistics 17 from SPSS software. Farreny et al [40] defined statistical analysis including descriptive statistics, variance analysis, correlation analysis, curvilinear estimation and lineal multiple regression. Chen et al [41] used the SPSS software for model calculation. All of these studies were compared each other in this study.

CUSUM (Cumulative Sum Deviation Method) is a numerical calculation for energy consumption analysis that determines the annual energy efficiency for factories. Similar studies use the cumulative sum (CUSUM). These previous studies are as follows:

Sun and Anwar [42] and Bastola and Sapkota [43] described CUSUM as the cumulative sum. CUSUM can examine the stability of the estimated model [42]. Farhani et al [44] used CUSUM to determine the stability in the parameters of the selected model. Lin and Moubarak [45] and Lim et al [46] testified to the stability of the model by using the cumulative sum (CUSUM) and CUSUMSQ (cumulative sum of squares test) of recursive residuals tests. Braga et al [47] also used the cumulative sum (CUSUM) to analyse the channel residuals. Ouyang and Lin [48] employed the cumulative sum of recursive residuals (CUSUM) and the CUSUM of squares (CUSUMSQ) to determine parameter balance. Wang et al [49] used the standard CUSUM control charts to view the residuals that were statistically independent.

Besides, many methods can be used in the energy management issues that are the various evolutionary algorithms like Genetic Algorithm, Particle Swarm Optimization, and Ant Colony Optimization etc. for solving the problems related with modelling of energy management analysis in previous literature. The application of evolutionary algorithms can be useful for considered problem. A multi-objective evolutionary algorithm was investigated for energy management of agricultural systems by Shamshirband $e t$ al [50]. Mogale et al [51] indicated a multi-period inventory transportation model for tactical planning of food grain. Mogale et al [52] researched the multi-period multi-modal bulk wheat transportation and storage problem in a twostage supply chain network of PDS (Public Distribution System). Banos et al [53] posed in computational optimization methods applied to renewable and sustainable 
Table 1. Material production - consumption and energy equation table.

\begin{tabular}{|c|c|c|c|c|c|c|}
\hline Period & Year/months & Material production $\mathrm{P}_{\mathrm{i}}[\mathrm{t}]$ & Energy consumption $\mathrm{E}_{\mathrm{j}}$ [Gcal] & $\mathrm{P}_{\mathrm{i}}^{2}$ & $\mathrm{E}_{\mathrm{j}}^{2}$ & $\mathrm{E}_{\mathrm{i}} \times \mathrm{P}_{\mathrm{i}}$ \\
\hline 1 & January & $\mathrm{P}_{1}$ & $\mathrm{E}_{1}$ & $\mathrm{P}_{1}^{2}$ & $\mathrm{E}_{1}^{2}$ & $\mathrm{E}_{1} \times \mathrm{P}_{1}$ \\
\hline 2 & February & $\mathrm{P}_{2}$ & $\mathrm{E}_{2}$ & $\mathrm{P}_{2}^{2}$ & $\mathrm{E}_{2}^{2}$ & $\mathrm{E}_{2} \times \mathrm{P}_{2}$ \\
\hline 3 & March & $\mathrm{P}_{3}$ & $\mathrm{E}_{3}$ & $\mathrm{P}_{3}^{2}$ & $\mathrm{E}_{3}^{2}$ & $\mathrm{E}_{3} \times \mathrm{P}_{3}$ \\
\hline 4 & April & $\mathrm{P}_{4}$ & $\mathrm{E}_{4}$ & $\mathrm{P}_{4}^{2}$ & $\mathrm{E}_{4}^{2}$ & $\mathrm{E}_{4} \times \mathrm{P}_{4}$ \\
\hline 5 & May & $\mathrm{P}_{5}$ & $\mathrm{E}_{5}$ & $\mathrm{P}_{5}^{2}$ & $\mathrm{E}_{5}^{2}$ & $\mathrm{E}_{5} \times \mathrm{P}_{5}$ \\
\hline 6 & June & $\mathrm{P}_{6}$ & $\mathrm{E}_{6}$ & $\mathrm{P}_{6}^{2}$ & $\mathrm{E}_{6}^{2}$ & $\mathrm{E}_{6} \times \mathrm{P}_{6}$ \\
\hline 7 & July & $\mathrm{P}_{7}$ & $\mathrm{E}_{7}$ & $\mathrm{P}_{7}^{2}$ & $\mathrm{E}_{7}^{2}$ & $\mathrm{E}_{7} \times \mathrm{P}_{7}$ \\
\hline 8 & August & $\mathrm{P}_{8}$ & $\mathrm{E}_{8}$ & $\mathrm{P}_{8}^{2}$ & $\mathrm{E}_{8}^{2}$ & $\mathrm{E}_{8} \times \mathrm{P}_{8}$ \\
\hline 9 & September & $\mathrm{P}_{9}$ & $\mathrm{E}_{9}$ & $\mathrm{P}_{9}^{2}$ & $\mathrm{E}_{9}^{2}$ & $\mathrm{E}_{9} \times \mathrm{P}_{9}$ \\
\hline 10 & October & $\mathrm{P}_{10}$ & $\mathrm{E}_{10}$ & $\mathrm{P}_{10}^{2}$ & $\mathrm{E}_{10}^{2}$ & $\mathrm{E}_{10} \times \mathrm{P}_{10}$ \\
\hline 11 & November & $\mathrm{P}_{11}$ & $\mathrm{E}_{11}$ & $\mathrm{P}_{11}^{2}$ & $\mathrm{E}_{11}^{2}$ & $\mathrm{E}_{11} \times \mathrm{P}_{11}$ \\
\hline 12 & December & $\mathrm{P}_{12}$ & $\mathrm{E}_{12}$ & $\mathrm{P}_{12}^{2}$ & $\mathrm{E}_{12}^{2}$ & $\mathrm{E}_{12} \times \mathrm{P}_{12}$ \\
\hline Year & Total & $\Sigma \mathrm{P}_{\mathrm{i}}$ & $\Sigma \mathrm{E}_{\mathrm{j}}$ & $\mathrm{P}_{\mathrm{i}}^{2}$ & $E_{j}^{2}$ & $\Sigma \mathrm{E}_{\mathrm{j}} \mathrm{P}_{\mathrm{i}}$ \\
\hline
\end{tabular}

energy. Maiyar and Thakkar [54] figured out particle swarm based optimization approach for a combined tactical and operational two-stage food grain transportation model. Mendes et al [55] investigated on the planning and analysis of Integrated Community Energy Systems. De et al [56] used PSO (Particle Swarm Optimization) - DE (Differential Evolution), GA (Genetic Algorithm) to validate their result of the study. Fong et al [57] researched HVAC (Heating, Ventilating and Air Conditioning) system optimization for energy management by evolutionary programming. Ene et al [58] studied a genetic algorithm for minimizing energy consumption in warehouses. Elsied et al [59] posed an advanced real time energy management system for microgrids in their study. Ruiz et al [60] studied a genetic algorithm for building envelope calibration. Paulo et al [61] and Benet et al [62] investigated genetic algorithms for maintenance plan optimization in these studies.

In this study, calculations of data analysis are an important issue for suggestions of energy saving to the management of factory. In addition, accurate and reliable data is crucial for energy management calculations. Therefore, SPPS was used to ensure the data's accuracy in this study (See in Appendix). Moreover, it can be said that the aim of an energy audit is to minimize the cost of energy, raw material and water. Thus, an audit can be useful in energy management for energy performance.

\section{A thermo-economic model on the calculation of energy consumption, material production and drawing the CUSUM chart}

Controlling the energy consumption and cost of processes is a boarding significant step for the energy efficiency survey. Therefore, there are many studies on energy efficiency and the use of energy in industries, recently [8-12]. Energy consumption, SEC (specific energy consumption), a material production amount and energy efficiency are calculated from these literature studies [7, 20, 22, 23, 25].

Energy consumption and a material production of the factory are shown in table 1 . Hereby, energy consumption means all of the energy used (electricity energy consumption, fuel consumption and other energy consumption) by the factory. Total energy consumptions are the sum of all energy consumptions in the same units for 12 months. Material production is the sum of the material production amounts in the same units for 12 months. In table 1, the material production and energy consumption amounts are calculated by the constants a and $b$. These variables are determined by the recursive least squares method. Thus, the energy equation can be obtained from this method.

The least squares method can be used to determine the energy equation. Cumulative sum (CUSUM) can be used to draw a CUSUM graph for these results. Using the least squares method, the linear (Energy) equation is as follows $[13,14,19,42,43]$;

$$
\mathrm{E}_{\mathrm{j}}=\mathrm{a}+\mathrm{b} \times \mathrm{P}_{\mathrm{i}}
$$

To obtain the energy equation, $\mathrm{a}$ and $\mathrm{b}$ are constants that are determined by the data of energy consumption. $\mathrm{P}_{\mathrm{i}}$ is a specific variable that also indicates the material production amount in the calculation. $E_{j}$ is the consumption of energy (Gcal and toe) on the vertical axis, $\mathrm{P}_{\mathrm{i}}$ is the material production amount $(t)$ on the horizontal axis, b is the slope of the line, and a is a slide in the horizontal axis. The calculation of the slope of the line $\mathrm{b}$ is as follows in Eq. (2);

$$
\mathrm{b}=\frac{\mathrm{n} \times \sum \mathrm{E}_{\mathrm{j}} \mathrm{P}_{\mathrm{i}}-\left(\sum \mathrm{P}_{\mathrm{i}}\right)\left(\sum \mathrm{E}_{\mathrm{j}}\right)}{\mathrm{n} \times \sum \mathrm{P}_{\mathrm{i}}^{2}-\left(\sum \mathrm{P}_{\mathrm{i}}\right)^{2}}
$$

where $b$ is the slope value of the line, $\sum E_{j} P_{i}$ is the multiplication of the amount of total energy consumption and material production, $\Sigma \mathrm{P}_{\mathrm{i}}$ is the sum of material production (unit is t), $\Sigma \mathrm{E}_{\mathrm{j}}$ is the sum of energy consumption (unit is 
Table 2. Calculation of the material production and energy consumption values table [13, 14, 20, 22, 25].

\begin{tabular}{|c|c|c|c|c|c|}
\hline Period & $\begin{array}{c}\text { Material } \\
\text { production value, } \\
\mathrm{P}_{\mathrm{i}}\end{array}$ & $\begin{array}{c}\text { Current energy } \\
\text { consumption value, } \mathrm{E}_{\mathrm{i}}\end{array}$ & $\begin{array}{l}\text { Theoretical energy } \\
\text { consumption value, }\left(\mathrm{a}+\mathrm{b} \times \mathrm{P}_{\mathrm{i}}\right)\end{array}$ & $\begin{array}{l}\text { Difference value, } \\
\qquad D_{\mathrm{i}}\end{array}$ & $\begin{array}{l}\text { Sum of CUSUM } \\
\text { value, } \mathrm{CS}_{\mathrm{i}}\end{array}$ \\
\hline January & $\mathrm{P}_{1}$ & $\mathrm{E}_{1}$ & $\mathrm{TE}_{1}$ & $\mathrm{D}_{1}=\left(\mathrm{E}_{1}-\mathrm{TE}_{1}\right)$ & $\mathrm{CS}_{1}=\left(\mathrm{D}_{1}\right)$ \\
\hline February & $\mathrm{P}_{2}$ & $\mathrm{E}_{2}$ & $\mathrm{TE}_{2}$ & $\mathrm{D}_{2}=\left(\mathrm{E}_{2}-\mathrm{TE}_{2}\right)$ & $\mathrm{CS}_{2}=\left(\mathrm{CS}_{1}+\mathrm{D}_{2}\right)$ \\
\hline March & $\mathrm{P}_{3}$ & $\mathrm{E}_{3}$ & $\mathrm{TE}_{3}$ & $\mathrm{D}_{3}=\left(\mathrm{E}_{3}-\mathrm{TE}_{3}\right)$ & $\mathrm{CS}_{3}=\left(\mathrm{CS}_{2}+\mathrm{D}_{3}\right)$ \\
\hline April & $\mathrm{P}_{4}$ & $\mathrm{E}_{4}$ & $\mathrm{TE}_{4}$ & $\mathrm{D}_{4}=\left(\mathrm{E}_{4}-\mathrm{TE}_{4}\right)$ & $\mathrm{CS}_{4}=\left(\mathrm{CS}_{3}+\mathrm{D}_{4}\right)$ \\
\hline May & $\mathrm{P}_{5}$ & $E_{5}$ & $\mathrm{TE}_{5}$ & $\mathrm{D}_{5}=\left(\mathrm{E}_{5}-\mathrm{TE}_{5}\right)$ & $\mathrm{CS}_{5}=\left(\mathrm{CS}_{4}+\mathrm{D}_{5}\right)$ \\
\hline June & $\mathrm{P}_{6}$ & $\mathrm{E}_{6}$ & $\mathrm{TE}_{6}$ & $\mathrm{D}_{6}=\left(\mathrm{E}_{6}-\mathrm{TE}_{6}\right)$ & $\mathrm{CS}_{6}=\left(\mathrm{CS}_{5}+\mathrm{D}_{6}\right)$ \\
\hline July & $\mathrm{P}_{7}$ & $\mathrm{E}_{7}$ & $\mathrm{TE}_{7}$ & $\mathrm{D}_{7=}\left(\mathrm{E}_{7}-\mathrm{TE}_{7}\right)$ & $\mathrm{CS}_{7}=\left(\mathrm{CS}_{6}+\mathrm{D}_{7}\right)$ \\
\hline August & $\mathrm{P}_{8}$ & $\mathrm{E}_{8}$ & $\mathrm{TE}_{8}$ & $\mathrm{D}_{8}=\left(\mathrm{E}_{8}-\mathrm{TE}_{8}\right)$ & $\mathrm{CS}_{8}=\left(\mathrm{CS}_{7}+\mathrm{D}_{8}\right)$ \\
\hline September & $\mathrm{P}_{9}$ & $\mathrm{E}_{9}$ & $\mathrm{TE}_{9}$ & $\mathrm{D}_{9}=\left(\mathrm{E}_{9}-\mathrm{TE}_{9}\right)$ & $\mathrm{CS}_{9}=\left(\mathrm{CS}_{8}++\mathrm{D}_{9}\right)$ \\
\hline October & $\mathrm{P}_{10}$ & $\mathrm{E}_{10}$ & $\mathrm{TE}_{10}$ & $\mathrm{D}_{10}=\left(\mathrm{E}_{10}-\mathrm{TE}_{10}\right)$ & $\mathrm{CS}_{10}=\left(\mathrm{CS}_{9}+\mathrm{D}_{10}\right)$ \\
\hline November & $\mathrm{P}_{11}$ & $\mathrm{E}_{11}$ & $\mathrm{TE}_{11}$ & $\mathrm{D}_{11}=\left(\mathrm{E}_{11}-\mathrm{TE}_{11}\right)$ & $\mathrm{CS}_{11}=\left(\mathrm{CS}_{10}+\mathrm{D}_{11}\right)$ \\
\hline December & $\mathrm{P}_{12}$ & $\mathrm{E}_{12}$ & $\mathrm{TE}_{12}$ & $\mathrm{D}_{12}=\left(\mathrm{E}_{12}-\mathrm{TE}_{12}\right)$ & $\mathrm{CS}_{12}=\left(\mathrm{CS}_{11}+\mathrm{D}_{12}\right)$ \\
\hline Final total & $\Sigma \mathrm{CS}_{\mathrm{i}}$ & & & & \\
\hline
\end{tabular}

Gcal), $\mathrm{n}$ is the data's number (period numbers are 12 ), and $\mathrm{P}_{\mathrm{i}}^{2}$ is the square of the total material production quantity. In Eq. (3), a is a slide value on the horizontal axis. The calculation slide in the horizontal axis is as follows in Eq. (3);

$$
\mathrm{a}=\frac{\sum \mathrm{E}_{\mathrm{j}}-\mathrm{b} \times \sum \mathrm{P}_{\mathrm{i}}}{\mathrm{n}}
$$

This analysis is important for defining a significant relationship between two variables. Therefore, a base line standard performance equation can be established using in regression analysis to measure the subsequent energy consumption for the CUSUM technique. The standard performance equation is first calculated, and the theoretical performance equation can be produced. CUSUM plot is produced by following steps. A standard performance equation is obtained to plot a scatter graph of the two variables under consideration. This technique uses the standard performance equation to calculate the estimated consumption of energy for each month that is deducted from the current consumption for each data point. CUSUM (Cumulative Sum Deviation Method) is acquired from the estimated consumption of energy for each month. Finally, the CUSUM value is plotted against time [13, 14, 20, 25, 42].

In table 2 , the calculation of the material production and energy consumption values can be observed as follows. The linear equation is determined using the regression analysis of the values of material production and energy consumption. The theoretical energy consumption for the sum of the CUSUM value can then be determined. Eq. (1) can be used to find the difference in the current energy consumption values and the theoretical energy consumption values, which can be used in the final total. Finally, the CUSUM graph is drawn with the result of the CUSUM values from the theoretical energy consumption values.

Thus, standard, SEC (specific energy consumption) and CUSUM can be calculated for any level of material production. The linear relationship between energy consumption and the material production indicator in the regression curve is determined as the accuracy of data $[13,14,17,19,20]$. In addition, in the calculations performed in Excel, the $r$ value is subtracted from the regression curve. The sum of the CUSUM values must be zero at the end of December. If it does not reach zero, there is an error in the calculations [22, 23, 25, 42, 47]. Wang et al [49] indicated that the CUSUM value will be reset to zero. When the $r$ value is close to 1 , the accuracy of calculation is better $[13,14,19,20,42]$.

\section{Results and Discussion}

In this section, the result of the energy consumption and production was calculated for the energy performance of the factory. Energy consumption and material production relationship was analysed for energy management programme. A cost of energy was determined for a technoeconomic analysis.

\subsection{The result of the energy consumption and production for the energy performance of the factory}

The last four years of energy consumption and material production data were taken from the sugar factory's administration and given in table 3 including the monthly production of sugar. The production rates are variable throughout the year, as shown in this table. Although there is no production in the spring and summer terms due to the campaign period, production decreases in autumn and winter. In tables 2, 3 and 4, the measured energy data and energy performance [27-31] are shown. 
Table 3. Monthly production of factories by year.

\begin{tabular}{lrrrr}
\hline \multirow{2}{*}{$\begin{array}{l}\text { Years } \\
\text { Period }\end{array}$} & $1^{\text {st }}$ year & $2^{\text {nd }}$ year & $3^{\text {rd }}$ year & $4^{\text {th }}$ year \\
\cline { 2 - 5 } January & 34,648 & 53,030 & 56,739 & 48,833 \\
February & 0 & 19,093 & 34,885 & 21,879 \\
March & 0 & 0 & 0 & 0 \\
April & 0 & 0 & 0 & 0 \\
May & 0 & 0 & 0 & 0 \\
June & 0 & 0 & 0 & 0 \\
July & 0 & 0 & 0 & 0 \\
August & 0 & 0 & 0 & 0 \\
September & 10,232 & 0 & 2,537 & 0 \\
October & 52,462 & 62,385 & 56,633 & 67,963 \\
November & 58,872 & 66,470 & 58,793 & 73,782 \\
December & 59,361 & 62,781 & 56,028 & 76,396 \\
Total production $[\mathrm{t}]$ & 215,575 & 263,759 & 265,618 & 288,853 \\
\hline
\end{tabular}

Table 4. Calorific values of energy consumption [13, 14].

\begin{tabular}{lccc}
\hline Quantity & $\begin{array}{c}\text { Source of } \\
\text { energy }\end{array}$ & $\begin{array}{c}\text { The heating } \\
\text { value }\end{array}$ & $\begin{array}{c}\text { Convert to toe } \\
\text { unit }\end{array}$ \\
\hline $1[\mathrm{t}]$ & $\begin{array}{c}\text { Pulverized } \\
\text { coal }\end{array}$ & $2300[\mathrm{kcal} / \mathrm{kg}]$ & 0.61 [toe] \\
$1000\left[\mathrm{~m}^{3}\right]$ & $\begin{array}{c}\text { Natural gas } \\
\text { Electricity }\end{array}$ & $8250\left[\mathrm{kcal} / \mathrm{m}^{3}\right]$ & $0.825[\mathrm{kcal} / \mathrm{kWh}]$ \\
1000 & & & $0.086[$ toe $]$ \\
{$[\mathrm{kWh}]$} & & & \\
\hline
\end{tabular}

$1[$ toe $]=10[\mathrm{Gcal}]=10^{7}[\mathrm{kcal}], 1[\mathrm{Gcal}]=0.1[\mathrm{toe}]$ and $1[\mathrm{kcal}]=10^{-6}$ [Gcal].

The consumption of energy data were taken from the factory's department of production. The energy consumption values were calculated from the calorific values for the heating value of pulverized coal, electricity and natural gas for the case of the factory. In table 4, these heating values and converted units were used in the calculations.

In this way, the consumption value was converted to Gcal units. In addition, the total consumption of energy was summed to include pulverized coal, network electricity, and natural gas, and the production of electricity from the energy of power plant for the factory was subtracted. The production of electricity has been determined for the energy management. These results are given in tables 5, 6, 7 and 8 .

Table 5 shows the results of energy consumption of the $1^{\text {st }}$ year. The sum of the energy consumption of coal was $230,885 \mathrm{Gcal}$. The sum of the energy consumption of network electricity was $8,998.61 \mathrm{Gcal}$. The sum of the energy consumption of the production of electricity was $-31,921.1$ Gcal. The sum of the energy consumption of natural gas was $20,925.84$ Gcal.

Table 6 shows the results of energy consumption of the $2^{\text {nd }}$ year. The sum of the energy consumption of coal was $335,846 \mathrm{Gcal}$. The sum of the energy consumption of network electricity was $40,121.70 \mathrm{Gcal}$. The sum of the energy consumption of the production of electricity was $-9,724.02$ Gcal. The sum of the energy consumption of natural gas was $59,332.56$ Gcal.

Table 7 shows the results of energy consumption of the $3^{\text {rd }}$ year. The sum of the energy consumption of coal was $372,255 \mathrm{Gcal}$. The sum of the energy consumption of network electricity was $11,476.52 \mathrm{Gcal}$. The sum of the energy consumption of the production of electricity was $-52,337.07$ Gcal. The sum of the energy consumption of natural gas was $78,019.01$ Gcal.

Table 8 shows the results of the energy consumption of the $4^{\text {th }}$ year. The sum of the energy consumption of coal was 328,246 Gcal. The sum of the energy consumption of network electricity was 22,001.54 Gcal. The sum of the energy consumption of the production of electricity was

Table 5. Monthly energy consumption of the factory in the $1^{\text {st }}$ year.

\begin{tabular}{|c|c|c|c|c|c|c|c|c|}
\hline \multirow{3}{*}{$\begin{array}{l}1^{\text {st }} \text { year } \\
\text { Month }\end{array}$} & \multicolumn{8}{|c|}{ Energy consumption } \\
\hline & \multicolumn{2}{|c|}{ Pulverized coal } & \multicolumn{2}{|c|}{ Network electricity } & \multicolumn{2}{|c|}{ Production of electricity } & \multicolumn{2}{|c|}{ Natural gas } \\
\hline & Gcal & $\mathrm{t}$ & Gcal & $\mathrm{kWh}$ & Gcal & $\mathrm{kWh}$ & Gcal & $\mathrm{m}^{3}$ \\
\hline January & 28,060 & 12,200 & 541.80 & 630,000 & $-4,713.6$ & $-5,481,032$ & $5,693.97$ & 690,178 \\
\hline February & 0 & 0 & $1,089.02$ & $1,266,300$ & 0 & 0 & 0 & 0 \\
\hline March & 0 & 0 & 958.99 & $1,115,100$ & 0 & 0 & 0 & 0 \\
\hline April & 0 & 0 & $1,050.40$ & $1,221,400$ & 0 & 0 & 0 & 0 \\
\hline May & 0 & 0 & 996.91 & $1,159,200$ & 0 & 0 & 0 & 0 \\
\hline June & 0 & 0 & 980.66 & $1,140,300$ & 0 & 0 & 0 & 0 \\
\hline July & 0 & 0 & $1,067.35$ & $1,241,100$ & 0 & 0 & 0 & 0 \\
\hline August & 0 & 0 & $1,121.53$ & $1,304,100$ & 0 & 0 & 0 & 0 \\
\hline September & 18,680 & 8,122 & 834.37 & 970,200 & $-2,041.9$ & $-2,374,385$ & 710.57 & 86,130 \\
\hline October & 62,067 & 26,986 & 75.85 & 88,200 & $-7,989.4$ & $-9,290,088$ & $8,247.19$ & 999,659 \\
\hline November & 54,887 & 23,864 & 119.20 & 138,600 & $-8,460.2$ & $-9,837,456$ & $2,660.86$ & 322,528 \\
\hline December & 67,189 & 29,213 & 162.54 & 189,000 & $-8,715.8$ & $-10,134,663$ & $3,613.25$ & 437,970 \\
\hline Sum & 230,885 & 100,385 & $8,998.61$ & $10,463,500$ & $-31,921.1$ & $-37,117,624$ & $20,925.84$ & $2,536,465$ \\
\hline
\end{tabular}


Table 6. Monthly energy consumption of the factory in the $2^{\text {nd }}$ year.

\begin{tabular}{|c|c|c|c|c|c|c|c|c|}
\hline \multirow{3}{*}{$\begin{array}{l}2^{\text {nd }} \text { year } \\
\text { Month }\end{array}$} & \multicolumn{8}{|c|}{ Energy consumption } \\
\hline & \multicolumn{2}{|c|}{ Pulverized coal } & \multicolumn{2}{|c|}{ Network electricity } & \multicolumn{2}{|c|}{ Production of electricity } & \multicolumn{2}{|c|}{ Natural gas } \\
\hline & Gcal & $\mathrm{t}$ & Gcal & $\mathrm{kWh}$ & Gcal & $\mathrm{kWh}$ & Gcal & $\mathrm{m}^{3}$ \\
\hline January & $62,385.20$ & 27,124 & $8,564.48$ & $9,958,696$ & -140.87 & $-163,800$ & $10,728.17$ & $1,300,384$ \\
\hline February & $29,900.00$ & 13,000 & $4,076.53$ & $4,740,152$ & -590.56 & $-686,700$ & $5,255.70$ & 637,054 \\
\hline March & 0 & 0 & 0 & 0 & $-1,289.48$ & $-1,499,400$ & $5,643.00$ & 684,000 \\
\hline April & 0 & 0 & 0 & 0 & -980.66 & $-1,140,300$ & $5,172.00$ & 626,850 \\
\hline May & 0 & 0 & 0 & 0 & $-1,099.08$ & $-1,278,000$ & $3,978.00$ & 482,156 \\
\hline June & 0 & 0 & 0 & 0 & $-1,202.28$ & $-1,398,000$ & $3,604.00$ & 436,820 \\
\hline July & 0 & 0 & 0 & 0 & $-1,452.02$ & $-1,688,400$ & $3,652.00$ & 442,700 \\
\hline August & $26,523.60$ & 11,532 & 0 & 0 & $-1,262.39$ & $-1,467,900$ & 257.00 & 31,150 \\
\hline September & $4,365.40$ & 1,898 & 0 & 0 & -845.21 & $-982,800$ & $1,054.00$ & 127,757 \\
\hline October & $69,000.00$ & 30,000 & $8,775.24$ & $10,203,773$ & -232.97 & $-270,900$ & $5,839.36$ & 707,801 \\
\hline November & $71,760.00$ & 31,200 & $9,170.97$ & $10,663,921$ & -222.14 & $-258,300$ & $6,968.92$ & 844,717 \\
\hline December & $71,911.80$ & 31,266 & $9,534.55$ & $11,086,684$ & -406.35 & $-472,500$ & $7,181.11$ & 870,437 \\
\hline Sum & $335,846.00$ & 146,020 & $40,121.70$ & $46,653,226$ & $-9,724.02$ & $-11,307,000$ & $59,332.56$ & $7,191,826$ \\
\hline
\end{tabular}

Table 7. Monthly energy consumption of the factory in the $3^{\text {rd }}$ year.

\begin{tabular}{|c|c|c|c|c|c|c|c|c|}
\hline \multirow{3}{*}{$\begin{array}{l}3^{\text {rd }} \text { year } \\
\text { Month }\end{array}$} & \multicolumn{8}{|c|}{ Energy consumption } \\
\hline & \multicolumn{2}{|c|}{ Pulverized coal } & \multicolumn{2}{|c|}{ Network electricity } & \multicolumn{2}{|c|}{ Production of electricity } & \multicolumn{2}{|c|}{ Natural gas } \\
\hline & Gcal & $\mathrm{t}$ & Gcal & $\mathrm{kWh}$ & Gcal & $\mathrm{kWh}$ & Gcal & $\mathrm{m}^{3}$ \\
\hline January & 74,945 & 32,585 & 357.59 & 415,800 & $-9,247.46$ & $-10,752,856$ & $5,835.21$ & 707,298 \\
\hline February & 54,949 & 23,891 & 249.23 & 289,800 & $-7,019.09$ & $-8,161,734$ & $4,051.76$ & 491,123 \\
\hline March & 0 & 0 & $1,714.80$ & $1,993,950$ & 0 & 0 & $5,982.24$ & 725,120 \\
\hline April & 0 & 0 & $1,370.75$ & $1,593,900$ & 0 & 0 & $5,117.97$ & 620,360 \\
\hline May & 0 & 0 & 547.22 & 636,300 & $-2,609.71$ & $-3,034,552$ & $3,284.56$ & 398,128 \\
\hline June & 0 & 0 & 363.01 & 422,100 & $-3,225.18$ & $-3,750,206$ & $1,436.75$ & 174,152 \\
\hline July & 0 & 0 & 893.97 & $1,039,500$ & $-2,037.22$ & $-2,368,866$ & $1,091.57$ & 132,312 \\
\hline August & 0 & 0 & $1,349.08$ & $1,568,700$ & 0 & 0 & $1,129.94$ & 136,962 \\
\hline September & 0 & 0 & $1,344.65$ & $1,563,541$ & -971.66 & $-1,129,840$ & 977.04 & 118,429 \\
\hline October & 86,434 & 37,580 & $1,193.42$ & $1,387,701$ & $-8,857.53$ & $-10,299,456$ & $14,519.97$ & $1,759,996$ \\
\hline November & 80,624 & 35,054 & 621.82 & 723,051 & $-8,923.88$ & $-10,376,600$ & $17,464.45$ & $2,116,903$ \\
\hline December & 75,302 & 32,740 & $1,470.99$ & $1,710,450$ & $-9,445.33$ & $-10,982,946$ & $17,127.55$ & $2,076,067$ \\
\hline Sum & 372,255 & 161,850 & $11,476.52$ & $13,344,793$ & $-52,337.07$ & $-60,857,056$ & $78,019.01$ & $9,456,850$ \\
\hline
\end{tabular}

$-48,772.70$ Gcal. The sum of the energy consumption of natural gas was $134,426.54$ Gcal.

According to table 9, the greatest energy consumption occurred in the $4^{\text {th }}$ year and the lowest energy consumption took place in the $1^{\text {st }}$ year.

In this study, the current unit of energy was used in the calculation of energy management. Previous studies used the toe unit in their energy calculation. Ashnani et al [63], Halder et al [64], Chadwick et al [65], Valero and Valero [66], and Popp et al [67] used the toe unit (tonnes oil equivalent) in their studies. In table 9, the results of the consumption of energy were converted from Gcal to toe. Thus, the energy calculation can use toe [63-67].

\subsection{Analysing the energy consumption and material production relationship}

The result of the $1^{\text {st }}$ year, $2^{\text {nd }}$ year, $3^{\text {rd }}$ year and $4^{\text {th }}$ year of production and energy consumption are given in tables 10 , 12 and 13, based on the energy consumption analysis tables created with the least squares method. The analysis of energy is performed according to the following energy equation in Excel. The results of the analysis of the energy consumption were taken into consideration based on table 2 for the last four years. The CUSUM values were also calculated from Eq. (4).

$$
E_{j}=a+b \times P_{i}
$$


Table 8. Monthly energy consumption of the factory in the $4^{\text {th }}$ year.

\begin{tabular}{|c|c|c|c|c|c|c|c|c|}
\hline \multirow{3}{*}{$\begin{array}{l}4^{\text {th }} \text { year } \\
\text { Month }\end{array}$} & \multicolumn{8}{|c|}{ Energy consumption } \\
\hline & \multicolumn{2}{|c|}{ Pulverized coal } & \multicolumn{2}{|c|}{ Network electricity } & \multicolumn{2}{|c|}{ Production of electricity } & \multicolumn{2}{|c|}{ Natural gas } \\
\hline & Gcal & $\mathrm{t}$ & Gcal & $\mathrm{kWh}$ & Gcal & $\mathrm{kWh}$ & Gcal & $\mathrm{m}^{3}$ \\
\hline January & 73,082 & 31,775 & $1,544.13$ & $1,795,500$ & $-9,936.67$ & $-11,554,262$ & $18,677.65$ & $2,263,958$ \\
\hline February & 29,012 & 12,614 & $1,576.64$ & $1,833,300$ & $-4,709.99$ & $-5,476,734$ & $9,355.62$ & $1,134,014$ \\
\hline March & 0 & 0 & $2,167.20$ & $2,520,000$ & 0 & 0 & $6,039.89$ & 732,108 \\
\hline April & 0 & 0 & $1,945.06$ & $2,261,700$ & 0 & 0 & $5,052.48$ & 612,422 \\
\hline May & 0 & 0 & $1,799.98$ & $2,093,004$ & 0 & 0 & $3,252.23$ & 394,210 \\
\hline June & 0 & 0 & $1,997.62$ & $2,322,810$ & -646.82 & $-752,116$ & $7,802.12$ & 945,712 \\
\hline July & 0 & 0 & $2,215.96$ & $2,576,700$ & $-1,213.20$ & $-1,410,700$ & $15,116.62$ & $1,832,317$ \\
\hline August & 0 & 0 & $2,329.74$ & $2,709,000$ & 0 & 0 & $3,901.06$ & 472,856 \\
\hline September & 0 & 0 & $2,403.05$ & $2,794,239$ & -288.27 & $-335,192$ & $1,058.90$ & 128,352 \\
\hline October & 79,455 & 34,546 & $1,039.71$ & $1,208,970$ & $-9,978.19$ & $-11,602,552$ & $18,604.95$ & $2,255,146$ \\
\hline November & 71,187 & 30,951 & $1,289.86$ & $1,499,841$ & $-10,423.18$ & $-12,119,980$ & $21,615.49$ & $2,620,059$ \\
\hline December & 75,509 & 32,830 & $1,692.58$ & $1,968,120$ & $-11,576.38$ & $-13,460,908$ & $23,949.88$ & $2,903,016$ \\
\hline Sum & 328,246 & 142,716 & $22,001.54$ & $25,583,184$ & $-48,772.70$ & $-56,712,444$ & $134,426.90$ & $16,294,170$ \\
\hline
\end{tabular}

Table 9. Total energy consumption of factories for four years.

\begin{tabular}{|c|c|c|c|c|c|c|c|c|}
\hline \multirow{3}{*}{$\begin{array}{l}\text { Year } \\
\text { Months }\end{array}$} & \multicolumn{8}{|c|}{ Total energy consumption } \\
\hline & \multicolumn{2}{|c|}{$1^{\text {st }}$ year } & \multicolumn{2}{|c|}{$2^{\text {nd }}$ year } & \multicolumn{2}{|c|}{$3^{\text {rd }}$ year } & \multicolumn{2}{|c|}{$4^{\text {th }}$ year } \\
\hline & Gcal & toe & Gcal & toe & Gcal & toe & Gcal & toe \\
\hline January & $29,582.08$ & $2,958.21$ & $81,536.98$ & $8,153.70$ & $71,890.84$ & $7,189.08$ & $83,367.62$ & $8,336.76$ \\
\hline February & $1,089.02$ & 108.90 & $38,641.66$ & $3,864.17$ & $52,231.20$ & $5,223.12$ & $35,234.46$ & $3,523.45$ \\
\hline March & 958.99 & 95.90 & $4,353.52$ & 435.35 & $7,697.04$ & 769.70 & $8,207.09$ & 820.71 \\
\hline April & $1,050.40$ & 105.04 & $4,190.85$ & 419.09 & $6,488.72$ & 648.87 & $6,997.54$ & 699.75 \\
\hline May & 996.91 & 99.69 & $2,878.71$ & 287.87 & $1,222.06$ & 122.21 & $5,052.22$ & 505.22 \\
\hline June & 980.66 & 98.07 & $2,401.49$ & 240.15 & $-1,425.42$ & -142.54 & $9,152.92$ & 915.29 \\
\hline July & $1,067.35$ & 106.73 & $2,200.25$ & 220.03 & -51.68 & -5.17 & $16,119.38$ & $1,611.94$ \\
\hline August & $1,121.53$ & 112.15 & $25,518.19$ & $2,551.82$ & $2,479.02$ & 247.90 & $6,230.80$ & 623.08 \\
\hline September & $18,183.57$ & $1,818.36$ & $4,574.19$ & 457.42 & $1,350.02$ & 135.00 & $3,173.68$ & 317.37 \\
\hline October & $62,401.36$ & $6,240.14$ & $83,381.63$ & $8,338.16$ & $93,289.86$ & $9,328.99$ & $89,122.27$ & $8,912.23$ \\
\hline November & $49,207.04$ & $4,920.70$ & $87,677.75$ & $8,767.77$ & $89,786.60$ & $8,978.66$ & $83,669.47$ & $8,366.95$ \\
\hline December & $62,249.88$ & $6,224.99$ & $88,221.10$ & $8,822.11$ & $84,455.21$ & $8,445.52$ & $89,575.08$ & $8,957.51$ \\
\hline Sum & $228,888.79$ & $22,888.88$ & $425,576.32$ & $42,557.63$ & $409,413.47$ & $40,941.35$ & $435,902.54$ & $43,590.25$ \\
\hline
\end{tabular}

The result of the $1^{\text {st }}$ year analysis of the total energy consumption is given in table 10 . The $1^{\text {st }}$ year energy equation is shown in Eq. (5);

$$
\mathrm{E}=163.89+0.0971 \times \mathrm{P}
$$

The result of the $2^{\text {nd }}$ year analysis of the total energy consumption is given in table 11 . The $2^{\text {nd }}$ year energy equation is shown in Eq. (6);

$$
\mathrm{E}=744.84+0.1275 \times \mathrm{P}
$$

The result of the $3^{\text {rd }}$ year analysis of the total energy consumption is given in table 12 . The $3^{\text {rd }}$ year energy equation is shown in Eq. (7);

$$
\mathrm{E}=200.96+0.1451 \times \mathrm{P}
$$

The result of the $4^{\text {th }}$ year analysis of the total energy consumption is given in table 13 . The $4^{\text {th }}$ year energy equation is shown in Eq. (8);

$$
\mathrm{E}=896.56+0.1137 \times \mathrm{P}
$$

From tables 10,11, 12 and 13, the results of the analysis of the energy consumption were taken into consideration based on table 2 for the last four years. The CUSUM values were also calculated. From tables $14,15,16$ and 17 , the $1^{\text {st }}, 2^{\text {nd }}, 3^{\text {rd }}$ and $4^{\text {th }}$ years' CUSUM values of December were zero, respectively. This result demonstrates the value's accuracy. The least squares method was used in this energy equation. 
Table 10. Energy equation of the $1^{\text {st }}$ year.

\begin{tabular}{|c|c|c|c|c|c|c|}
\hline Period & Months & Production, $\mathrm{P}[\mathrm{t}]$ & Energy consumption, E [toe] & $\mathrm{P}^{2}$ & $E^{2}$ & $E \times P$ \\
\hline 1 & January & $34,648.00$ & $2,958.21$ & $1,200,483,904.00$ & $8,750,995.15$ & 102495994.18 \\
\hline 2 & February & 0 & 108.90 & 0 & $11,859.60$ & 0 \\
\hline 3 & March & 0 & 95.90 & 0 & $9,196.54$ & 0 \\
\hline 4 & April & 0 & 105.04 & 0 & $11,033.49$ & 0 \\
\hline 5 & May & 0 & 99.69 & 0 & $9,938.34$ & 0 \\
\hline 6 & June & 0 & 98.07 & 0 & $9,616.90$ & 0 \\
\hline 7 & July & 0 & 106.73 & 0 & $11,392.27$ & 0 \\
\hline 8 & August & 0 & 112.15 & 0 & $12,578.21$ & 0 \\
\hline 9 & September & $10,231.80$ & $1,818.36$ & $104,689,731.24$ & $3,306,423.42$ & $18,605,068.63$ \\
\hline 10 & October & $52,461.64$ & $6,240.14$ & $2,752,223,356.72$ & $38,939,301.13$ & $327,367,765.77$ \\
\hline 11 & November & $58,872.39$ & $4,920.70$ & $3,465,958,068.82$ & $24,213,327.70$ & $289,693,594.18$ \\
\hline 12 & December & $59,360.97$ & $6,224.99$ & $3,523,724,996.78$ & $38,750,478.49$ & $369,521,352.14$ \\
\hline $1^{\text {st }}$ year & Sum & $215,574.80$ & $22,888.88$ & $11,047,080,057.57$ & $114,036,141.23$ & $1,107,683,774.90$ \\
\hline
\end{tabular}

$\mathrm{b}=0.0971$.

$\mathrm{a}=163.89$.

$\mathrm{E}=163.89+0.0971 \times \mathrm{P}$.

Table 11. Energy equation of the $2^{\text {nd }}$ year.

\begin{tabular}{|c|c|c|c|c|c|c|}
\hline Period & Months & Production, $\mathrm{P}[\mathrm{t}]$ & Energy consumption, E [toe] & $\mathrm{P}^{2}$ & $E^{2}$ & $\mathrm{E} \times \mathrm{P}$ \\
\hline 1 & January & $53,030.42$ & $8,153.70$ & $2,812,225,445.38$ & $66,482,788.73$ & $432,394,021.86$ \\
\hline 2 & February & $19,092.78$ & $3,864.17$ & $364,534,362.69$ & $14,931,782.14$ & $73,777,690.97$ \\
\hline 3 & March & 0 & 435.35 & 0 & $189,531.02$ & 0 \\
\hline 4 & April & 0 & 419.09 & 0 & $175,632.61$ & 0 \\
\hline 5 & May & 0 & 287.87 & 0 & $82,869.54$ & 0 \\
\hline 6 & June & 0 & 240.15 & 0 & $57,671.30$ & 0 \\
\hline 7 & July & 0 & 220.03 & 0 & $48,411.04$ & 0 \\
\hline 8 & August & 0 & $2,551.82$ & 0 & $6,511,782.00$ & 0 \\
\hline 9 & September & 0 & 457.42 & 0 & $209,231.89$ & 0 \\
\hline 10 & October & $62,384.71$ & $8,338.16$ & $3,891,851,542.71$ & $69,524,960.60$ & $520,173,841.28$ \\
\hline 11 & November & $66,469.78$ & $8,767.77$ & $4,418,231,786.19$ & $76,873,877.24$ & $582,792,079.52$ \\
\hline 12 & December & $62,781.32$ & $8,822.11$ & $3,941,494,140.94$ & $77,829,631.01$ & $553,863,732.90$ \\
\hline $2^{\text {nd }}$ year & Sum & $263,759.01$ & $42,557.63$ & $15,428,337,277.90$ & $312,918,169.11$ & $2,163,001,366.53$ \\
\hline
\end{tabular}

The CUSUM graphs were plotted according to the results of the CUSUM values (in compliance with tables 10, 11, 12 and 13) in Microsoft Excel Software. The regression curve increased each year. The CUSUM chart's curve shows that the factory makes a profit in the negative zone and suffers a loss in the positive zone [13,14, 20, 23, 25].

In figure 2 , the energy efficiency of the factory was good with low energy consumption. The linear regression analysis of the chart resulted in an $\mathrm{R}^{2}$ value of 0.2909 . The energy efficiency increased through August in the $1^{\text {st }}$ year for the factory. The maximum energy efficiency of the factory decreased in October.

Figure 3 shows that the energy consumption of the factory increased and the energy efficiency of the factory decreased in the $2^{\text {nd }}$ year. The linear regression analysis is shown, in which the $R^{2}$ is 0.2108 . The maximum energy efficiency increased in July, and the energy efficiency of the factory fell in February.

Figure 4 illustrates that the energy consumption of the factory decreased and the energy efficiency of the factory increased in the $3^{\text {rd }}$ year. The linear regression analysis is shown, in which $\mathrm{R}^{2}$ is 0.3004 . The maximum energy efficiency increased in February and September, and the energy efficiency of the factory fell in April and November.

Figure 5 depicts that the energy consumption of the factory increased and the energy efficiency of the factory decreased in the $4^{\text {th }}$ year. This year was the worst for energy efficiency. The linear regression analysis is shown, 
Table 12. Energy equation of the $3^{\text {rd }}$ year.

\begin{tabular}{ccccccc}
\hline Period & Months & Production, P [t] & Energy Consumption, E [toe] & $\mathrm{P}^{2}$ & $\mathrm{E}^{2}$ & $\mathrm{E} \times \mathrm{P}$ \\
\hline 1 & January & $56,739.53$ & $7,189.08$ & $3,219,374,718.54$ & $51,682,929.25$ & $407,905,277.98$ \\
2 & February & $34,885.75$ & $5,223.12$ & $1,217,015,413.52$ & $27,280,984.11$ & $182,212,453.36$ \\
3 & March & 0 & 769.70 & 0 & $592,443.79$ & 0 \\
4 & April & 0 & 648.87 & 0 & $421,035.39$ & 0 \\
5 & May & 0 & 122.21 & 0 & 0 & 0 \\
6 & June & 0 & -142.54 & 0 & $20,318.14$ & 26.71 \\
7 & July & 0 & -5.17 & 0 & $61,455.33$ & 0 \\
8 & August & 0 & 247.90 & $6,438,906.25$ & $18,225.60$ & $342,568.11$ \\
9 & September & $2,537.50$ & 135.00 & $3,3207,350,377.31$ & $87,029,975.50$ & $528,332,873.05$ \\
10 & October & $56,633.47$ & $8,978.66$ & $3,456,709,154.63$ & $80,616,331.10$ & $527,889,391.58$ \\
11 & November & $58,793.79$ & $8,445.52$ & $3,139,143,619.42$ & $71,326,818.53$ & $473,186,144.42$ \\
12 & December & $56,028.06$ & $40,941.35$ & $14,246,032,189.66$ & $319,065,477.73$ & $2,119,868,708.49$ \\
$3^{\text {rd }}$ year & Sum & $265,618.10$ & & & 0 \\
\hline
\end{tabular}

$\mathrm{b}=0.1451$

$\mathrm{a}=200.96$.

$\mathrm{E}=200.96+0.1451 \times \mathrm{P}$.

Table 13. Energy equation of the $4^{\text {th }}$ year.

\begin{tabular}{ccccccc}
\hline Period & Months & Production, P [t] & Energy Consumption, E [toe] & $\mathrm{P}^{2}$ & $\mathrm{E}^{2}$ & $\mathrm{E}$ x P \\
\hline 1 & January & $48,833.14$ & $8,336.76$ & $2,384,675,562.26$ & $69,501,597.61$ & $407,110,257.01$ \\
2 & February & $21,879.04$ & $3,523.45$ & $478,692,391.32$ & $12,414,673.31$ & $77,089,620.92$ \\
3 & March & 0 & 820.71 & 0 & $673,563.43$ & 0 \\
4 & April & 0 & 699.75 & 0 & $489,656.15$ \\
5 & May & 0 & 505.22 & 0 & $255,248.86$ \\
6 & June & 0 & 915.29 & 0 & $837,759.60$ & 0 \\
7 & July & 0 & $1,611.94$ & 0 & $2,598,342.58$ & 0 \\
8 & August & 0 & 623.08 & 0 & $388,228.94$ & 0 \\
9 & September & 0 & 317.37 & 0 & $100,722.73$ \\
10 & October & $67,962.89$ & $8,912.23$ & $4,618,954,009.37$ & $79,427,797.19$ & $605,700,703.57$ \\
11 & November & $73,782.47$ & $8,366.95$ & $5,443,853,026.87$ & $70,005,797.43$ & $617,334,003.80$ \\
12 & December & $76,395.56$ & $8,957.51$ & $5,836,281,282.13$ & $80,236,957.31$ & $684,313,854.95$ \\
$4^{\text {th }}$ year & Sum & $288,853.10$ & $43,590.25$ & $18,762,456,271.95$ & $316,930,345.14$ & $2,391,548,440.24$ \\
\hline
\end{tabular}

$\mathrm{b}=0.1137$.

$\mathrm{a}=896.56$.

$\mathrm{E}=896.56+0.1137 \times \mathrm{P}$.

in which $R^{2}$ is 0.5535 . The maximum energy efficiency increased in November, and the energy efficiency of the factory fell in July.

\subsection{Cost of energy and a techno-economic analysis}

The cost of energy is energy consumption of the production in energy management. Similar previous studies approached this analysis in different way [2, 3, 6, 14, 68]. Thus, the cost of energy can be found from a techno-economic analysis of the economic feasibility of an energy system. Specific energy consumptions (SEC) can give the cost of energy. SEC was calculated in several previous studies $[8,13,14,17,25]$. The cost of energy was also calculated for the sugar factory. In table 18, the results of the energy consumption were taken from tables from 10,11 12 and 13.

Thermoeconomic is a technique for analysing the cost of energy through a combination of the $2^{\text {nd }}$ Law of Thermodynamics and economic principles [3, 6, 71-73]. Karaali and Ozturk [73] defined thermoeconomic optimization method, which is a simple and efficient method. This can be viewed as cost analysis and optimization [3, 6, 71, 72]. This definition is the key of thermoeconomic. The unit of energy cost is defined as follows $[3,6,71,72]$ : 
Table 14. CUSUM values of the $1^{\text {st }}$ year.

\begin{tabular}{|c|c|c|c|c|c|}
\hline Months & $\begin{array}{c}\text { Production } \\
{[\mathrm{t}]}\end{array}$ & $\begin{array}{l}\text { Energy consumption } \\
\text { [toe] }\end{array}$ & $\begin{array}{l}\text { Theoretical energy consumption }(\mathrm{a}+\mathrm{b} \times \\
\mathrm{P})\end{array}$ & $\begin{array}{l}\text { Difference } \\
\text { value }\end{array}$ & $\begin{array}{l}\text { CUSUM } \\
\text { value }\end{array}$ \\
\hline January & $34,648.00$ & $2,958.21$ & $3,527.05$ & -568.84 & -568.84 \\
\hline February & 0 & 108.90 & 163.39 & -54.49 & -623.33 \\
\hline March & 0 & 95.90 & 163.39 & -67.49 & -690.82 \\
\hline April & 0 & 105.04 & 163.39 & -58.35 & -749.17 \\
\hline May & 0 & 99.69 & 163.39 & -63.70 & -812.87 \\
\hline June & 0 & 98.07 & 163.39 & -65.32 & -878.19 \\
\hline July & 0 & 106.73 & 163.39 & -56.65 & -934.84 \\
\hline August & 0 & 112.15 & 163.39 & -51.24 & -986.08 \\
\hline September & $10,231.80$ & $1,818.36$ & $1,156.70$ & 661.66 & -324.43 \\
\hline October & $52,461.64$ & $6,240.14$ & $5,256.42$ & 983.72 & 659.29 \\
\hline November & $58,872.39$ & $4,920.70$ & $5,878.78$ & -958.07 & -298.78 \\
\hline December & $59,360.97$ & $6,224.99$ & $5,926.21$ & 298.78 & 0 \\
\hline
\end{tabular}

Table 15. CUSUM values of the $2^{\text {nd }}$ year.

\begin{tabular}{|c|c|c|c|c|c|}
\hline Months & $\begin{array}{l}\text { Production } \\
{[\mathrm{t}]}\end{array}$ & $\begin{array}{c}\text { Energy consumption } \\
\text { [toe] }\end{array}$ & $\begin{array}{c}\text { Theoretical energy consumption }(\mathrm{a}+\mathrm{b} \times \\
\mathrm{P})\end{array}$ & $\begin{array}{l}\text { Difference } \\
\text { value }\end{array}$ & $\begin{array}{l}\text { CUSUM } \\
\text { value }\end{array}$ \\
\hline January & $53,030.42$ & $8,153.70$ & $7,504.26$ & 649.44 & 649.44 \\
\hline February & $19,092.78$ & $3,864.17$ & $3,178.47$ & 685.70 & $1,335.14$ \\
\hline March & 0 & 435.35 & 744.84 & -309.49 & $1,025.65$ \\
\hline April & 0 & 419.09 & 744.84 & -325.76 & 699.89 \\
\hline May & 0 & 287.87 & 744.84 & -456.97 & 242.92 \\
\hline June & 0 & 240.15 & 744.84 & -504.69 & -261.78 \\
\hline July & 0 & 220.03 & 744.84 & -524.82 & -786.59 \\
\hline August & 0 & $2,551.82$ & 744.84 & $1,806.98$ & $1,020.38$ \\
\hline September & 0 & 457.42 & 744.84 & -287.42 & 732.96 \\
\hline October & $62,384.71$ & $8,338.16$ & $8,696.59$ & -358.42 & 374.54 \\
\hline November & $66,469.78$ & $8,767.77$ & $9,217.28$ & -449.51 & -74.97 \\
\hline December & $62,781.32$ & $8,822.11$ & $8,747.14$ & 74.97 & 0 \\
\hline
\end{tabular}

Table 16. CUSUM values of the $3^{\text {rd }}$ year.

\begin{tabular}{|c|c|c|c|c|c|}
\hline Months & $\begin{array}{l}\text { Production } \\
{[\mathrm{t}]}\end{array}$ & $\begin{array}{c}\text { Energy consumption } \\
\text { [toe] }\end{array}$ & $\begin{array}{l}\text { Theoretical energy consumption }(\mathrm{a}+\mathrm{b} \times \\
\mathrm{P})\end{array}$ & $\begin{array}{l}\text { Difference } \\
\text { value }\end{array}$ & $\begin{array}{l}\text { CUSUM } \\
\text { value }\end{array}$ \\
\hline January & $56,739.53$ & $7,189.08$ & $8,431.44$ & $-1,242.36$ & $-1,242.36$ \\
\hline February & $34,885.75$ & $5,223.12$ & $5,261.39$ & -38.27 & $-1,280.63$ \\
\hline March & 0 & 769.70 & 200.96 & 568.74 & -711.88 \\
\hline April & 0 & 648.87 & 200.96 & 447.91 & -263.97 \\
\hline May & 0 & 122.21 & 200.96 & -78.75 & -342.72 \\
\hline June & 0 & -142.54 & 200.96 & -343.50 & -686.22 \\
\hline July & 0 & -5.17 & 200.96 & -206.13 & -892.35 \\
\hline August & 0 & 247.90 & 200.96 & 46.94 & -845.41 \\
\hline September & $2,537.50$ & 135.00 & 569.04 & -434.04 & $-1,279.45$ \\
\hline October & $56,633.47$ & $9,328.99$ & $8,416.06$ & 912.93 & -366.52 \\
\hline November & $58,793.79$ & $8,978.66$ & $8,729.42$ & 249.24 & -117.28 \\
\hline December & $56,028.06$ & $8,445.52$ & $8,328.24$ & 117.28 & 0 \\
\hline
\end{tabular}


Table 17. CUSUM values of the $4^{\text {th }}$ year.

\begin{tabular}{|c|c|c|c|c|c|}
\hline Months & $\begin{array}{c}\text { Production } \\
{[\mathrm{t}]}\end{array}$ & $\begin{array}{c}\text { Energy consumption } \\
\text { [toe] }\end{array}$ & $\begin{array}{l}\text { Theoretical energy consumption }(\mathrm{a}+\mathrm{b} \times \\
\mathrm{P})\end{array}$ & $\begin{array}{l}\text { Difference } \\
\text { value }\end{array}$ & $\begin{array}{l}\text { CUSUM } \\
\text { value }\end{array}$ \\
\hline January & $48,833.14$ & $8,336.76$ & $6,447.02$ & $1,889.74$ & $1,889.74$ \\
\hline February & $21,879.04$ & $3,523.45$ & $3,383.37$ & 140.08 & $2,029.82$ \\
\hline March & 0 & 820.71 & 896.56 & -75.85 & $1,953.97$ \\
\hline April & 0 & 699.75 & 896.56 & -196.80 & $1,757.17$ \\
\hline May & 0 & 505.22 & 896.56 & -391.34 & $1,365.83$ \\
\hline June & 0 & 915.29 & 896.56 & 18.74 & $1,384.57$ \\
\hline July & 0 & $1,611.94$ & 896.56 & 715.38 & $2,099.95$ \\
\hline August & 0 & 623.08 & 896.56 & -273.48 & $1,826.47$ \\
\hline September & 0 & 317.37 & 896.56 & -579.19 & $1,247.28$ \\
\hline October & $67,962.89$ & $8,912.23$ & $8,621.34$ & 290.88 & $1,538.17$ \\
\hline November & $73,782.47$ & $8,366.95$ & $9,282.81$ & -915.86 & 622.31 \\
\hline December & $76,395.56$ & $8,957.51$ & $9,579.82$ & -622.31 & 0 \\
\hline
\end{tabular}

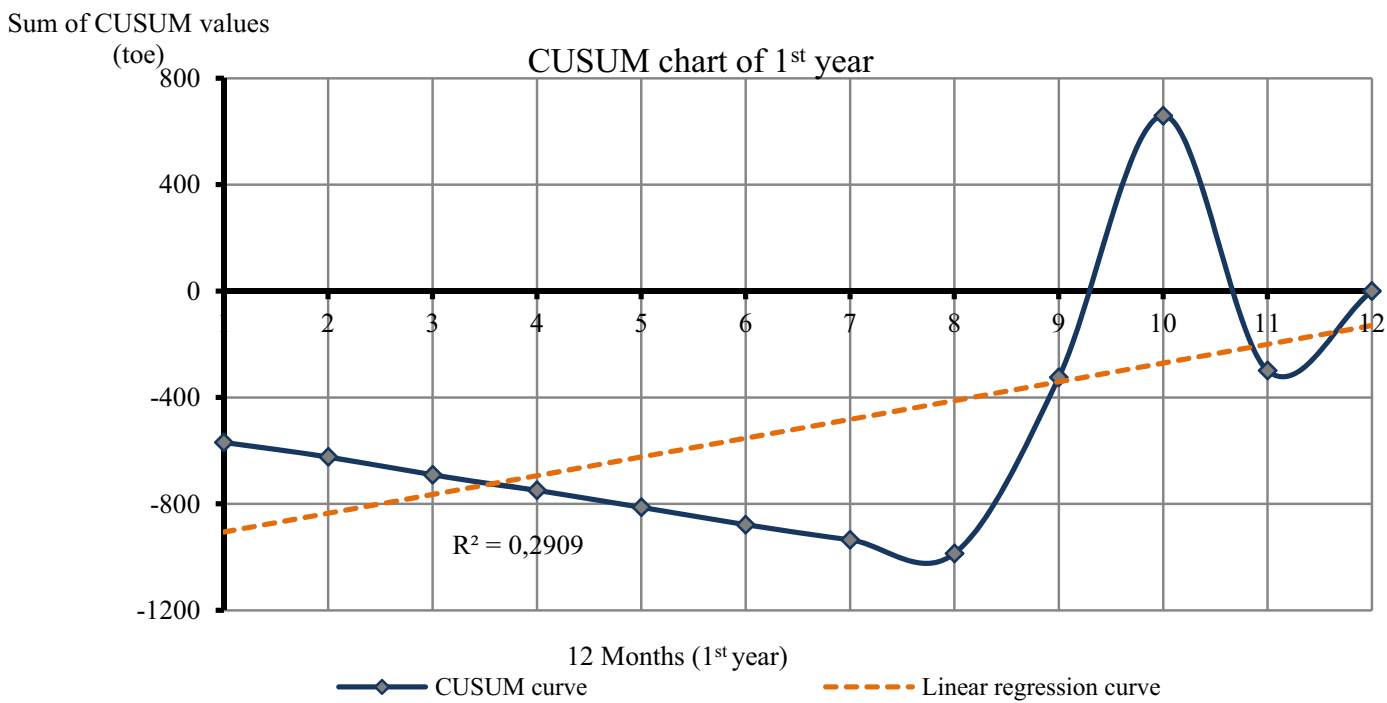

Figure 2. CUSUM chart of the $1^{\text {st }}$ year.

$$
\dot{\mathrm{C}}_{\mathrm{En}}[\$ / \text { toe }]=\frac{\mathrm{C}_{\text {cost }}[\$]}{\mathrm{E}_{\mathrm{e}}[\text { toe }]}
$$

where $\dot{\mathrm{C}}_{\mathrm{En}}$ is the unit of energy cost. $\mathrm{C}_{\text {cost }}$ is the total investment cost (the capital cost, depreciation cost, operating and maintenance cost, and energy-power cost). The total investment cost was taken as 30,000,000 [\$] according to the factory accounting department. $\mathrm{E}_{\mathrm{e}}$ is the total energy consumption as shown in table 18.

$$
\mathrm{SEC}\left[\frac{\text { toe }}{\mathrm{t}}\right]=\frac{\mathrm{E}_{\mathrm{e}}[\mathrm{toe}]}{\mathrm{P}[t]},
$$

where SEC is the specific energy consumption which was 0.1062 [toe/t] for the first year. The unit of energy cost was 688.22 [\$/toe] for the last year. From these results, it can be observed that the $4^{\text {th }}$ year is the best among them. Therefore, the optimisation of the factory was reached in the $4^{\text {th }}$ year. The factory increased the power plant's energy and took several energy precautions.

The CUSUM charts of the last four years were compared with respect to their energy consumption and energy efficiencies in figure 6 . The $3^{\text {rd }}$ year of the factory's energy efficiency was found as the best among them. Therefore, the energy plant of the factory's power was increased in the $3^{\text {rd }}$ year. Additionally, the $4^{\text {th }}$ year of factory's energy consumption increased more than the other years. The $4^{\text {th }}$ year of the factory's energy performance was found to be the worst among them. So, these results showed that Energy Efficiency of Turkish Law and Directives [74, 75] required factories to have an energy manager. 


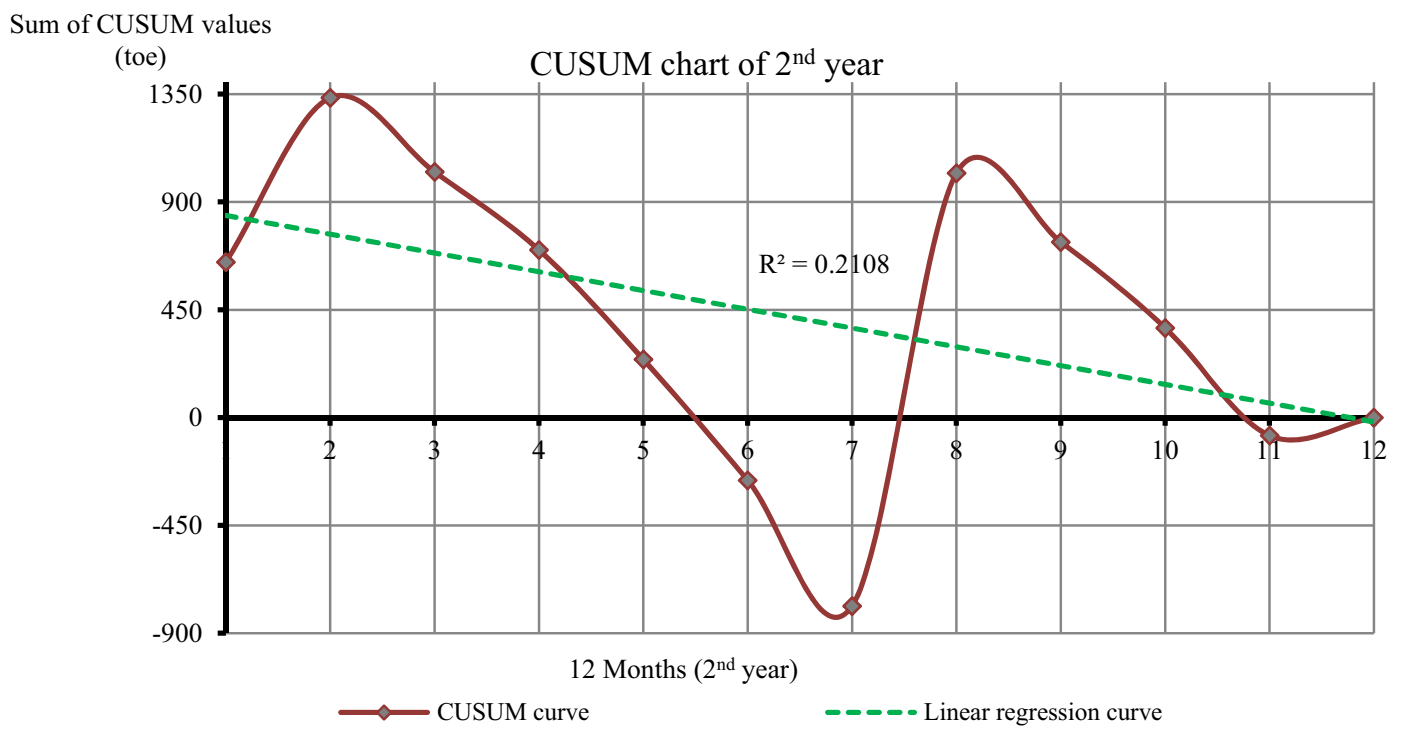

Figure 3. CUSUM chart of the $2^{\text {nd }}$ year.

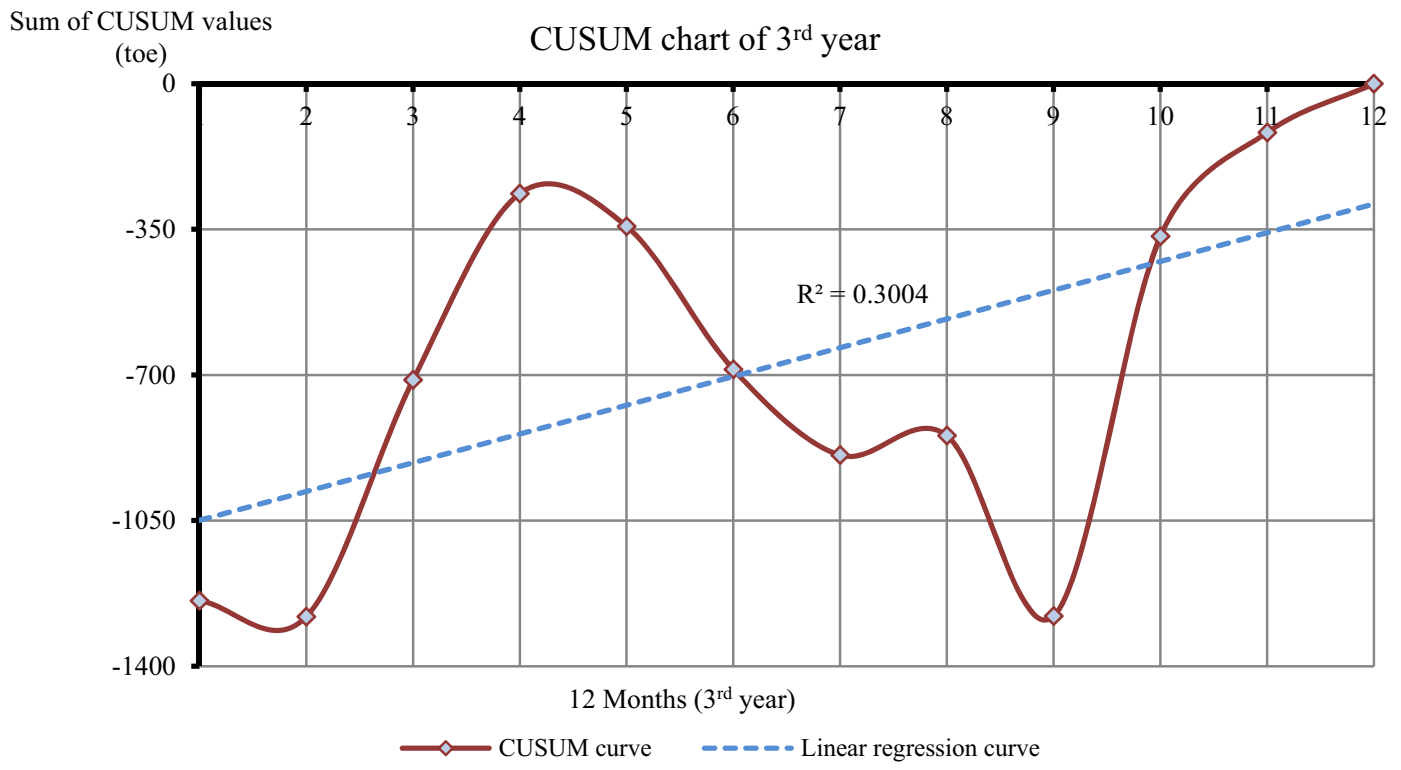

Figure 4. CUSUM chart of the $3^{\text {rd }}$ year.

\section{Conclusions}

In conclusion, the factory's management made a decision to decrease the power plant's energy production. Thus, the production of sugar beets decreased in this year, and they could not increase the production of energy.

In this study, the data accuracy was investigated by SPSS statistical software, as documented in the Appendix. The results of the CUSUM energy values were used to obtain a mathematical relation for the last four years using SPSS 17.0. The results proved the relation between the production data (independent variable) and the energy consumption data (dependent variable). The Appendix section includes a detailed step by step method. The statistical techniques ensured data accuracy for this study.

The unit of energy cost was 688.22 [\$/toe] for the last year. The obtained results are found to be compatible with previous studies. Finally, it was seen that the factory can 


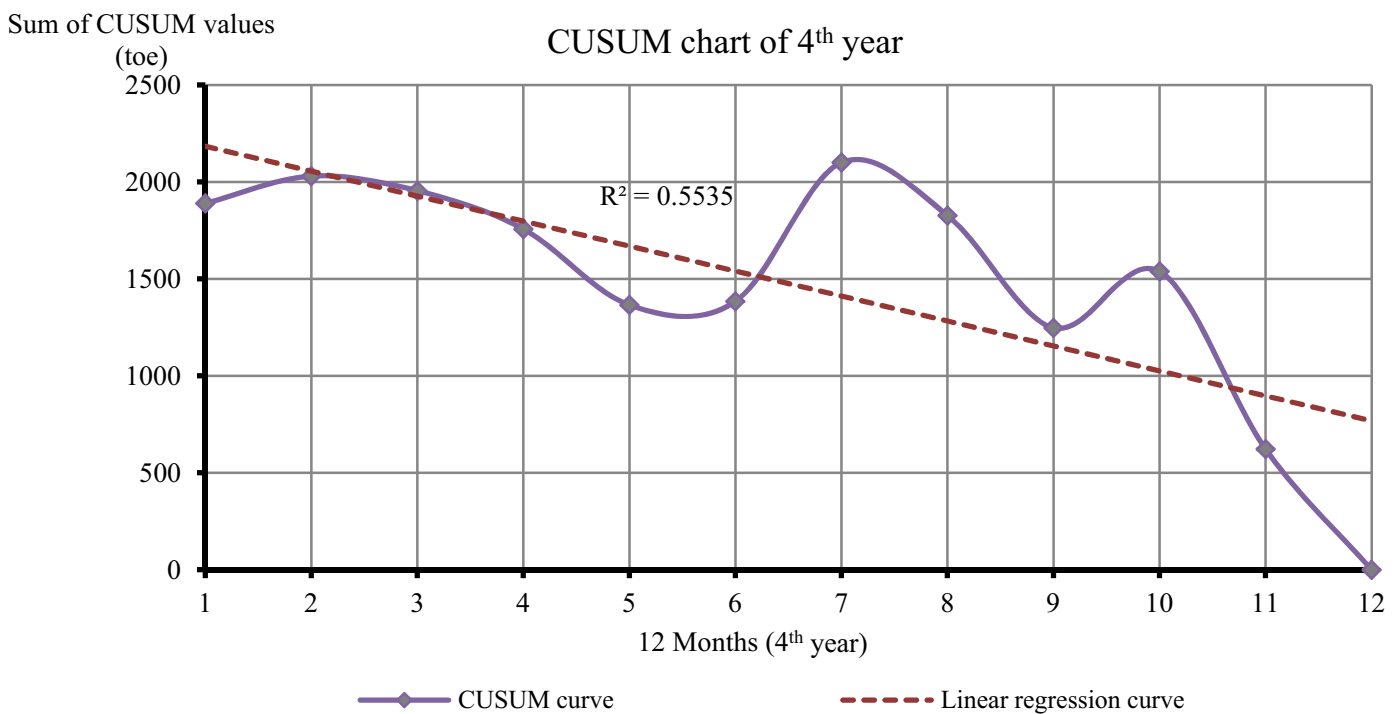

Figure 5. CUSUM chart of the $4^{\text {th }}$ year.

Table 18. Cost of energy from the total production - consumption of energy values for the last year and the optimisation year.

\begin{tabular}{|c|c|c|c|c|c|c|c|}
\hline Year & $\begin{array}{l}\text { P total of sugar } \\
\text { production } \\
\text { amount }[\mathrm{t}]\end{array}$ & $\begin{array}{l}\mathrm{P}_{\mathrm{pr}} \text {, total sale } \\
\text { price }^{\mathrm{a}}[\$]\end{array}$ & $\begin{array}{c}\mathrm{E}_{\mathrm{p}}, \text { total } \\
\text { energy } \\
\text { production } \\
\text { [toe] }\end{array}$ & $\begin{array}{c}\mathrm{E}_{\mathrm{e}}, \text { total energy } \\
\text { consumption } \\
\text { [toe] }\end{array}$ & $\begin{array}{c}\mathrm{E}_{\text {cost }} \text {, cost of } \\
\text { energy } \\
\text { consumption }^{\mathrm{b}}[\$]\end{array}$ & $\begin{array}{l}\text { SEC, specific } \\
\text { consumption } \\
\text { energy [toe/t] }\end{array}$ & $\begin{array}{c}\dot{\mathrm{C}}_{\mathrm{En}} \text {, The unit of } \\
\text { energy cost } \\
(\$ / \text { toe })\end{array}$ \\
\hline $1^{\text {st }}$ & 215,574 & $250,713,492.4$ & $3,192.11$ & $22,888.88$ & $2,288,888$ & 0.1062 & $1,310.68$ \\
\hline $2^{\text {nd }}$ & 263,759 & $306,751,717.0$ & $9,724.02$ & $42,557.63$ & $4,255,763$ & 0.1613 & 704.92 \\
\hline $3^{\text {rd }}$ & 265,618 & $308,913,734.0$ & $5,233.71$ & $40,941.35$ & $4,094,135$ & 0.1541 & 732.75 \\
\hline $4^{\text {th }}$ & 288,853 & $335,936,155.3$ & $4,877.27$ & $43,590.25$ & $4,359,025$ & 0.1509 & 688.22 \\
\hline
\end{tabular}

${ }^{a}$ Price of sugar taken from the Official of Turkish Sugar Factory Incorporeal [69] was 1.163 [\$/kg].

${ }^{\mathrm{b}}$ Energy consumption price was taken from the International Energy Agency [70] publication from the table of average prices and taxes in Turkish liras. A heavy fuel oil for electricity generation price was 2456 Turkish liras per tonne, which converted to approximately $100[\$ / t]$. In addition, $100[\$ / t]$ is equivalent to 100 [\$/toe].This equivalent was taken from the General Directorate of Renewable Energy [68].

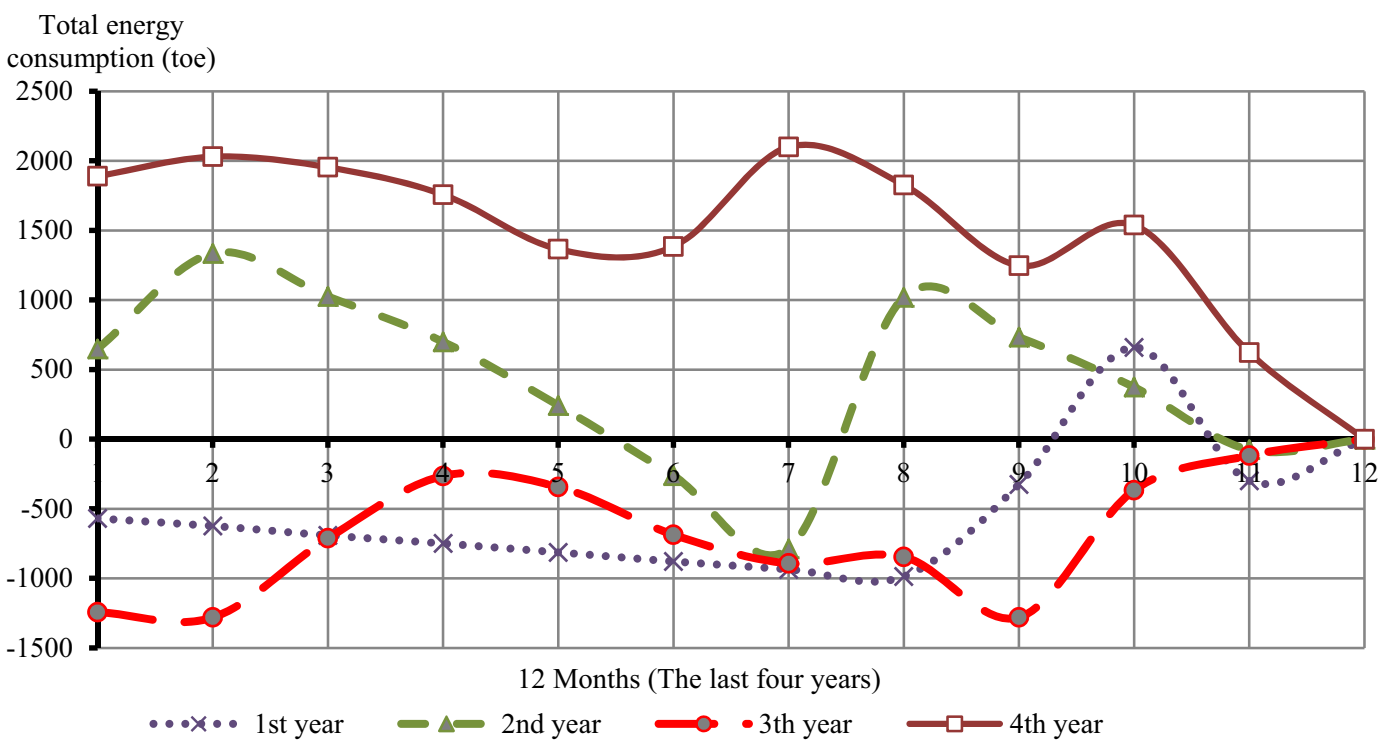

Figure 6. CUSUM Chart's comparison of the last four years. 
decrease the unit of energy by optimisation. In conclusion, this study proved that the sugar factory should employ an energy manager to comply with the Energy Efficiency of Turkish Law and Legislation. Regrettably, it was understood that it dispended energy consumption of 43,590.25 [toe] for the last year. If factories have an energy consumption greater than 1,000 toes, they must include an energy manager for their factory. Although the unit of energy cost is more feasible than in the other years, specific energy consumption is not as good as the other years. According to the proposal, the unit of energy cost can be taken over 688.22 [\$/toe] when energy management is completed by all departments of the factory, immediately. Consequently, the specific consumption of energy can be decreased by energy management.

\section{Appendix}

In this study, SPSS Statistic Method was used for data accuracy and prediction, which was previously proved for this method. All years were investigated for accuracy. In this study, regression analysis was performed in SPPS Statistic 17.0 package. The figures and results show the energy consumption and production relationship, which was significant for each year. The Multi Linear Regression Model was used in this study. The model output is given in the Appendix, which also provides comments on the statistical technique for these outputs. This study used methods similar to previous studies. Kalayci [38] used SPSS to apply multivariate statistical techniques, including regression analysis. In the Appendix, these results were fitted according to the previous studies [41-45].

The $1^{\text {st }}, 2^{\text {nd }}, 3^{\text {rd }}$ and $4^{\text {th }}$ years are the same in figure 7. Entered variable is uretim $^{\mathrm{a}}$ (production). a means that all requested variables were entered, and $b$ means that the dependent variable is tuketim (energy consumption). Variables Entered/Removed ${ }^{\mathrm{b}}$ used the Enter Method in figure 7.
Model Summary ${ }^{\mathrm{b}}$ gave the model summary of the energy consumption and production in table $19 . \mathrm{R}^{2}$ indicates the percentage of the dependent variable explained by the independent variables. In these results, the $\mathrm{R}^{2}$ value was 0.961 for the $1^{\text {st }}$ year, 0.966 for the $2^{\text {nd }}$ year, 0.981 for the $3^{\text {rd }}$ year and 0.962 for the $4^{\text {th }}$ year. The $\mathrm{R}^{2}$ value indicated the accuracy of the data to be close to 1 .

ANOVA $^{b}$ is the analysis of variance of the energy consumption and production in table 20. The ANOVA Table presents the entire model to detect the significance of the test. In these results, the F-test value was 244.882 for the $1^{\text {st }}$ year, 283.630 for the $2^{\text {nd }}$ year, 527.780 for the $3^{\text {rd }}$ year and 253.373 for the $4^{\text {th }}$ year. All Sig. Values are 0,000 . These results showed that the models are significant for each year.

In table 21, Coefficients ${ }^{\mathrm{a}}$ (Parameter Prediction) shows the prediction values that relate to the $t$ values. When the unit of product increases, the consumption of energy increases. The results of the model's prediction equation for all years are as follows:

The equation of the $1^{\text {st }}$ year was $\mathrm{y}=163.384+0.097 \mathrm{x}$, the equation of the $2^{\text {nd }}$ year was $y=744.845+0.127 \mathrm{x}$, the equation of the $3^{\text {rd }}$ year was $y=200.959+0.145 \mathrm{x}$, and the equation of the $4^{\text {th }}$ year was $y=896.556+0.114 \mathrm{x}$.

where $\mathrm{y}$ shows the energy consumption, and $\mathrm{x}$ shows the production. This appendix presented the data accuracy. All of the year's data were accurate.

The Residuals Statistics ${ }^{\mathrm{a}}$ results are shown in table 22. The Mean of Predicted Values was 1,907.41 for the $1^{\text {st }}$ year, 3,546.47 for the $2^{\text {nd }}$ year, $3,411.78$ for the $3^{\text {rd }}$ year and $3,632.52$ for the $4^{\text {th }}$ year. The Standard Deviation of Residuals Values was 501.02 for the $1^{\text {st }}$ year, 708.18 for the $2^{\text {nd }}$ year, 550.67 for the $3^{\text {rd }}$ year and 739.87 for the $4^{\text {th }}$ year. The Standard Predicted Value was 1.00 for all years. The Standard Residual values were 0.95 for all years.

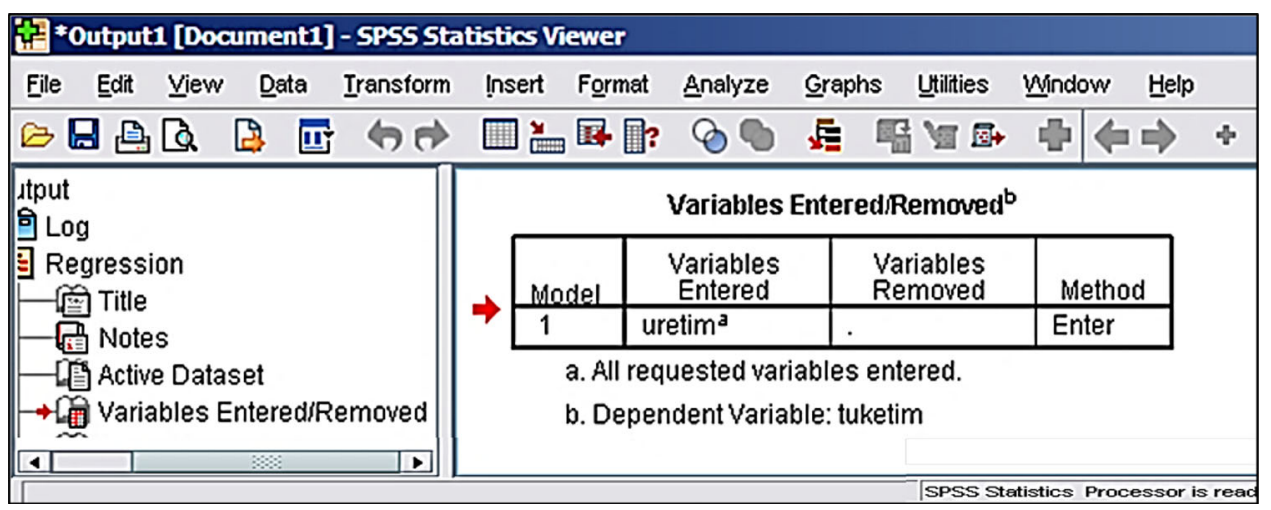

Figure 7. Variables Entered/Removed ${ }^{\mathrm{b}}$ input from the SPSS package programme. 
Table 19. Model Summary ${ }^{\mathrm{b}}$ output of energy consumption and production relationship from the SPSS package

\begin{tabular}{|c|c|c|c|c|c|c|c|c|c|c|}
\hline \multirow[b]{2}{*}{ Year } & \multirow[b]{2}{*}{ Model } & \multirow[b]{2}{*}{$\mathrm{R}$} & \multirow[b]{2}{*}{$\begin{array}{c}\mathrm{R} \\
\text { square }\end{array}$} & \multirow[b]{2}{*}{$\begin{array}{l}\text { Adjusted R } \\
\text { square }\end{array}$} & \multirow[b]{2}{*}{$\begin{array}{c}\text { Standard error of the } \\
\text { estimate }\end{array}$} & \multicolumn{5}{|c|}{ Change statistics } \\
\hline & & & & & & $\begin{array}{l}\mathrm{R} \text { square } \\
\text { change }\end{array}$ & $\begin{array}{c}F \\
\text { change }\end{array}$ & df1 & df 2 & $\begin{array}{l}\text { Sig.F } \\
\text { change }\end{array}$ \\
\hline $1^{\text {st }}$ & 1 & $0.980^{\mathrm{a}}$ & 0.961 & 0.957 & 525.47 & 0.961 & 244.882 & 1 & 10 & 0.000 \\
\hline $2^{\text {nd }}$ & 1 & $0.983^{\mathrm{a}}$ & 0.966 & 0.963 & 742.75 & 0.981 & 283.630 & 1 & 10 & 0.000 \\
\hline $3^{\text {rd }}$ & 1 & $0.991^{\mathrm{a}}$ & 0.981 & 0.980 & 577.55 & 0.981 & 527.780 & 1 & 10 & 0.000 \\
\hline $4^{\text {th }}$ & 1 & $0.981^{\mathrm{a}}$ & 0.962 & 0.958 & 775.98 & 0.962 & 253.373 & 1 & 10 & 0.000 \\
\hline
\end{tabular}

${ }^{\text {a }}$ Predictor, which is production (constant).

${ }^{\mathrm{b}}$ Dependent variable, which is energy consumption.

Table 20. ANOVA $^{\mathrm{b}}$ output of the energy consumption and production relationship from the SPSS package.

\begin{tabular}{lccccc}
\hline Year & Model 1 & Sum of squares & df & Mean square & F \\
\hline $1^{\text {st }}$ & Regression & $6.762 \times 10^{7}$ & 1 & $6.762 \times 10^{7}$ & 244.882 \\
& Residual & $2,761,185.964$ & 10 & $276,118.596$ & $0.000^{\mathrm{a}}$ \\
& Total & $7.038 \times 10^{7}$ & 11 & & \\
$2^{\text {nd }}$ & Regression & $1.565 \times 10^{8}$ & 1 & $1.565 \times 10^{8}$ & 283.630 \\
& Residual & $5,516,759.021$ & 10 & $551,675.902$ & $0.000^{\mathrm{a}}$ \\
& Total & $1.620 \times 10^{8}$ & 11 & & 527.780 \\
$3^{\text {rd }}$ & Regression & $1.760 \times 10^{8}$ & 1 & $1.760 \times 10^{8}$ & $0.000^{\mathrm{a}}$ \\
& Residual & $3,335,614.798$ & 10 & $333,561.480$ & \\
& Total & $1.794 \times 10^{8}$ & 11 & & \\
$4^{\text {th }}$ & Regression & $1.526 \times 10^{8}$ & 1 & $1.526 \times 10^{8}$ & 253.373 \\
& Residual & $6,021,412.467$ & 10 & $602,141.247$ & $0.000^{\mathrm{a}}$
\end{tabular}

${ }^{a}$ Predictors i.e., production (constant).

${ }^{\mathrm{b}}$ Dependent variable that is energy consumption.

Table 21. Coefficients ${ }^{\mathrm{a}}$ output of energy consumption and production relationship from the SPSS package.

\begin{tabular}{|c|c|c|c|c|c|c|c|c|}
\hline \multirow[b]{2}{*}{ Year } & \multirow[b]{2}{*}{ Model 1} & \multicolumn{2}{|c|}{ Unstandardized coefficients } & \multirow{2}{*}{$\begin{array}{c}\text { Standardized Coefficients } \\
\text { Beta }\end{array}$} & \multirow[b]{2}{*}{$\mathrm{t}$} & \multirow[b]{2}{*}{ Sig. } & \multicolumn{2}{|c|}{$95.0 \%$ Confidence Interval for B } \\
\hline & & B & Std. Error & & & & Lower bound & Upper bound \\
\hline \multirow[t]{2}{*}{$1^{\mathrm{st}}$} & (Constant) Uretim & 163.384 & 188.230 & & 0.868 & 0.406 & -256.019 & 582.787 \\
\hline & & 0.097 & 0.006 & 0.980 & 15.649 & 0.000 & 0.083 & 0.111 \\
\hline \multirow[t]{2}{*}{$2^{\text {nd }}$} & (Constant) Uretim & 744.845 & 271.379 & & 2.745 & 0.021 & 140.174 & $1,349.515$ \\
\hline & & 0.127 & 0.008 & 0.983 & 16.841 & 0.000 & 0.111 & 0.144 \\
\hline \multirow[t]{2}{*}{$3^{\text {rd }}$} & (Constant) Uretim & 200.959 & 217.555 & & 0.924 & 0.377 & -283.784 & 685.702 \\
\hline & & 0.145 & 0.006 & 0.991 & 22.973 & 0.000 & 0.131 & 0.159 \\
\hline \multirow[t]{2}{*}{$4^{\text {th }}$} & (Constant) Uretim & 896.556 & 282.351 & & 3.175 & 0.010 & 267.440 & $1,525.673$ \\
\hline & & 0.114 & 0.007 & 0.981 & 15.918 & 0.000 & 0.098 & 0.130 \\
\hline
\end{tabular}

${ }^{a}$ Dependent variable, i.e., energy consumption.

Uretim means production (constant).

In this study, Reliability Analysis (Scale Alpha) was investigated with the SPSS package. Table 23 shows the reliability data for the last four years. In this
Table, Cronbach's Alpha Based on the Standardized Items was nearly 0.99 for all years. These results indicate strong data reliability because the results are 
Table 22. Residuals statistics ${ }^{\mathrm{a}}$ output of the energy consumption and production relationship from the SPSS package.

\begin{tabular}{|c|c|c|c|c|c|c|}
\hline \multirow[b]{2}{*}{ Year } & & \multicolumn{5}{|c|}{ Residuals statistics $^{\mathrm{a}}$} \\
\hline & & Minimum & Maximum & Mean & Standard deviation & $\mathrm{N}$ \\
\hline \multirow[t]{4}{*}{$1^{\text {st }}$} & Predicted value & 163.38 & $5,926.22$ & $1,907.41$ & $2,479.31$ & 12 \\
\hline & Residual & -958.05 & 983.68 & 0.00 & 501.02 & 12 \\
\hline & Standard predicted value & -0.70 & 1.62 & 0.00 & 1.00 & 12 \\
\hline & Standard residual & -1.82 & 1.87 & 0.00 & 0.95 & 12 \\
\hline \multirow[t]{4}{*}{$2^{\text {nd }}$} & Predicted value & 744.84 & $9,217.28$ & $3,546.47$ & $3,771.57$ & 12 \\
\hline & Residual & -524.82 & $1,806.98$ & 0.00 & 708.18 & 12 \\
\hline & Standard predicted value & -0.743 & 1.50 & 0.00 & 1.00 & 12 \\
\hline & Standard residual & -0.707 & 2.43 & 0.00 & 0.95 & 12 \\
\hline \multirow[t]{4}{*}{$3^{\text {rd }}$} & Predicted value & 200.9588 & $8,729.42$ & $3,411.78$ & $4,000.54$ & 12 \\
\hline & Residual & $-1,242.36$ & 912.94 & 0.00 & 550.67 & 12 \\
\hline & Standard predicted value & -0.80 & 1.33 & 0.00 & 1.00 & 12 \\
\hline & Standard residual & -2.15 & 1.58 & 0.00 & 0.95 & 12 \\
\hline \multirow[t]{4}{*}{$4^{\text {th }}$} & Predicted value & 896.56 & $9,579.82$ & $3,632.52$ & $3,724.20$ & 12 \\
\hline & Residual & -915.86 & $1,889.74$ & 0.00 & 739.87 & 12 \\
\hline & Standard predicted value & -0.735 & 1.59 & 0.00 & 1.00 & 12 \\
\hline & Standard residual & -1.180 & 2.44 & 0.00 & 0.95 & 12 \\
\hline
\end{tabular}

${ }^{\mathrm{a}}$ Dependent variable: energy consumption (tuketim).

Table 23. Reliability analysis (Scale Alpha) output of the energy consumption and production relationship from the SPSS package.

\begin{tabular}{lccc}
\hline & \multicolumn{2}{c}{ Reliability statistics } \\
\cline { 3 - 4 } Year & $\begin{array}{c}\text { Cronbach's } \\
\text { alpha }\end{array}$ & $\begin{array}{c}\text { Cronbach's alpha based on } \\
\text { standardized items }\end{array}$ & $\begin{array}{c}\text { Number of } \\
\text { items }\end{array}$ \\
\hline $1^{\text {st }}$ & 0.323 & 0.990 & 2 \\
$2^{\text {nd }}$ & 0.401 & 0.991 & 2 \\
$3^{\text {rd }}$ & 0.442 & 0.995 & 2 \\
$4^{\text {th }}$ & 0.366 & 0.990 & 2 \\
\hline
\end{tabular}

very near 1 . Statistics scale alpha gives the data reliability [38].

\section{Acknowledgement}

This study was supported by a Scientific Research (Date of work: February 2010 to January 2013) for the case of a sugar factory in Turkey. It was carried out in Çumra Sugar Integrated Plant. The energy data were taken with permission from the factory administration having in collaboration with the Department of Factory Central Monitoring and Directorate of Maintenance and Energy.

\section{List of symbols}

$\dot{\mathrm{C}}_{\mathrm{En}} \quad$ the unit of energy cost, \$/toe

$\mathrm{E}_{\mathrm{e}}$ total energy consumption, toe

a slide in the horizontal axis b slope of the line in the horizontal axis

$\mathrm{C}_{\text {cost }}$ total investment cost, $\$$

$\mathrm{CS}_{\mathrm{i}}$ sum of CUSUM value

$\mathrm{D}_{\mathrm{i}}$ difference value

E energy consumption, Gcal; toe

$\mathrm{E}_{\mathrm{j}} \quad$ consumption of energy amount, toe

$\mathrm{E}_{\mathrm{p}} \quad$ total energy production, toe

$\mathrm{i}, \mathrm{j}$ notation

$\mathrm{P} \quad$ material production, tonnes

$\mathrm{P}_{\mathrm{i}} \quad$ specific variable of material production amounts, tonnes

$\mathrm{P}_{\mathrm{pr}} \quad$ total sale price, $\$$

$\mathrm{R}^{2} \quad \mathrm{R}$ Squared (Linear regression analysis symbol)

$\mathrm{t}$ tonnes

$\begin{array}{ll}\text { Abbreviations } \\ \text { ANOVA } & \text { analysis of variance } \\ \text { CUSUM } & \text { cumulative sum } \\ \text { CUSUMSQ } & \begin{array}{l}\text { cumulative sum of squares } \\ \text { differential evolution }\end{array} \\ \text { DE } & \text { genetic algorithm } \\ \text { GA } & \text { heating, ventilating and air conditioning } \\ \text { HVAC } & \text { predictive analytics software } \\ \text { PASW } & \text { public distribution system } \\ \text { PDS } & \text { particle swarm optimization } \\ \text { PSO } & \text { specific energy consumptions, toe/t } \\ \text { SEC } & \text { statistical package for the social sciences }\end{array}$

Greek symbols

$\Sigma$ Sum 


\section{References}

[1] Palensky P and Dietrich D 2011 Demand side management: demand response, intelligent energy systems, and smart loads. IEEE Trans. Ind. Informat. 7(3): 381-388

[2] Wang L 2009 Energy Project Management in Food Processing, Facilities Energy Efficiency and Management in Food Processing Facilities. New York: CRC Press

[3] Taner T and Sivrioglu M 2014 Thermoeconomic analysis for the power plants of sugar factories. J. Faculty Eng. Architect. Gazi Univ. 29(2): 407-414

[4] Abdelaziz E A, Saidur R and Mekhilef S 2011 A review on energy saving strategies in industrial sector. Renew. Sustain. Energy Rev. 15: 150-168

[5] Petrecca G 1993 Industrial Energy Management: Principles and Applications. Massachusetts: Kluwer Academic Publisher

[6] Taner T 2015 Optimisation processes of energy efficiency for a drying plant: a case of study for Turkey. Appl. Thermal Eng. 80: 247-260

[7] Kannan R and Boie W 2003 Energy management practices in SME_-case study of a bakery in Germany. Energy Conver. Manag. 44: 945-59

[8] Giacone E and Mancò S 2012 Energy efficiency measurement in industrial processes. Energy 38: 331-345

[9] Bunsea K, Vodicka M, Schönslebena P, Brülhart M and Ernst F O 2011 Integrating energy efficiency performance in material production management e gap-analysis between industrial needs and scientific literature. J. Cleaner Mater. Prod. 19: 667-679

[10] Tanaka K 2008 Assessment of energy efficiency performance measures in industry and their application for policy. Energy Policy 36: 2887-2902

[11] Gielen D and Taylor P 2009 Indicators for industrial energy efficiency in India. Energy 34: 962-969

[12] Palamutcu S 2010 Electric energy consumption in the cotton textile processing stages. Energy 35: 2945-2952

[13] Taner T 2002 Energy Management for Turkish Industry. MSc Thesis, Denizli: Pamukkale University Institute of Science [in Turkish]

[14] Republic of Turkey Ministry of Energy and Natural Resources 2014 General Directorate of Renewable Energy. Energy management principle for industry. Volume I, Fourth Revision, Ankara, Turkey [in Turkish]

[15] Ramirez C A, Patel M and Blok K 2006 From fluid milk to milk powder: energy use and energy efficiency in the European dairy industry. Energy 31: 1984-2004

[16] Ramirez C A, Patel M and Blok K 2006 How much energy to process one pound of meat? A comparison of energy use and specific energy consumption in the meat industry of four European countries. Energy 31: 2047-2063

[17] Xu T, Flapper J and Kramer K J 2009 Characterization of energy use and performance of global cheese processing. Energy 34: 1993-2000

[18] Dörr M, Wahren S and Bauernhans T 2013 Methodology for energy efficiency on process level. Procedia CIRP 7: $652-657$

[19] Zhang J, Deng S, Shen F, Yang X, Liu G, Guo H, Li Y, Hong X, Zhang Y, Peng H, Zhang X, Li L and Wang Y 2011 Modeling the relationship between energy consumption and economy development in China. Energy 36: 4227-4234
[20] Department of Minerals and Energy Pretoria 2005 Industrial Energy Management Training Course, Module 7: Energy Monitoring, Targeting \& Reporting. Republic of South Africa: 1-34. Available from: www.energy.gov.za/EEE/ Projects, Access date: 05/01/2015

[21] Morvay Z and Gvozdenac D 2008 Applied Industrial Energy and Environmental Management. Chicester: John Wiley \& Sons Ltd

[22] Beggs C 2002 Energy: Management, Supply and Conversation. Oxford: Butterworth-Heinemann

[23] Sustainable Energy Authority of Ireland 1996 Department of the Environment, Investment Appraisal for Industrial Energy Efficiency, Good Practice Guide 69. Oxfordshire Available from: www.seai.ie/Archive1, Access date: 10/01/2015

[24] Blatt S 1996 The facilities manager's energy primer, Good Practice Guide 69. British Institute of Facilities Management, Department of the Environment and the Royal Institution of Chartered Surveyors, Cambridge Available from: www.carltd.com/sites/carwebsite, Access date: 10/01/2015

[25] Turner W and Doty S 2006 Energy Management Handbook. 6th edition. Georgia: The Fairmont Press

[26] Chen J, Wang X and Steemers K 2013 A statistical analysis of a residential energy consumption survey study in Hangzhou, China. Energy Build. 66: 193-202

[27] Reilly D, Duffy A, Willis D and Conlon M 2013 Development and implementation of a simplified residential energy asset rating model. Energy Build. 65: 159-166

[28] Mavromatidis G, Acha S and Shah N 2013 Diagnostic tools of energy performance for supermarkets using Artificial Neural Network algorithms. Energy Build. 62: 304-314

[29] Díaz J J V, Wilby M R, González A B R and Munoz J G 2013 EEOnt: an ontological model for a unified representation of energy efficiency in buildings. Energy Build. 60: 20-27

[30] Gul M S and Patidar S 2015 Understanding the energy consumption and occupancy of a multi-purpose academic building. Energy Build. 2015: 87:155-165

[31] Granderson J, Piette M A and Ghatikar G 2011 Building energy information systems: user case studies. Energy Efficiency 4: 17-30

[32] Chen S, Li N, Guan J, Xie Y, Sun F and Ni J 2008 A statistical method to investigate national energy consumption in the residential building sector of China. Energy Build. 40: 654-665

[33] Aranda A, Ferreira G, Mainar-Toledo M D, Scarpellini S and Sastresa E L 2012 Multiple regression models to predict the annual energy consumption in the Spanish banking sector. Energy Build. 49: 380-387

[34] Turhan C, Kazanasmaz T, Uygun I E, Ekmen K E and Akkurt G G 2014 Comparative study of a building energy performance software (KEP-IYTE-ESS) and ANN-based building heat load estimation. Energy Build. 85: 115-125

[35] Huebner G M, Cooper J and Jones K 2013 Domestic energy consumption-What role do comfort, habit, and knowledge about the heating system play? Energy Build. 66: 626-636

[36] Orosa J A and Oliveira A C 2011 Reducing energy peak consumption with passive climate control methods. Energy Build. 43: 2282-2288

[37] Choi I Y, Cho S H and Kim J T 2012 Energy consumption characteristics of high-rise apartment buildings according to 
building shape and mixed-use development. Energy Build. 46: $123-131$

[38] Kalayci S 2010 SPSS Applied Multivariate Statistical Techniques. Ankara: Asil Publishing

[39] Aksozen M, Daniel M, Hassler U and Kohler N 2015 Building age as an indicator for energy consumption. Energy Build. 87: 74-86

[40] Farreny R, Oliver-Solà J, Escuder-Bonilla S, Roca-Martí M, Sevigné E, Gabarrell X and Rieradevall J 2012 The metabolism of cultural services. Energy and water flows in museums. Energy Build. 47: 98-106

[41] Chen S, Yoshino H and Li N 2010 Statistical analyses on summer energy consumption characteristics of residential buildings in some cities of China. Energy Build. 42: 136-146

[42] Sun S and Anwar S 2015 Electricity consumption, industrial production, and entrepreneurship in Singapore. Energy Policy 77: 70-78

[43] Bastola U and Sapkota P 2015 Relationships among energy consumption, pollution emission, and economic growth in Nepal. Energy 80: 254-262

[44] Farhani S, Chaibi A and Rault C $2014 \mathrm{CO}_{2}$ emissions, output, energy consumption, and trade in Tunisia. Econ. Model. 38: $426-434$

[45] Lin B and Moubarak M 2014 Renewable energy consumption - Economic growth nexus for China. Renew. Sustain. Energy Rev. 40: 111-117

[46] Lim K M, Lim S Y and Yoo S H 2014 Short- and long-run elasticities of electricity demand in the Korean service sector. Energy Policy 67: 517-521

[47] Braga L C, Braga A R and Braga C M P 2013 On the characterization and monitoring of building energy demand using statistical process control methodologies. Energy Build. 65: 205-219

[48] Ouyang X and Lin B 2014 A projection of future electricity intensity and conservation potential in the Chinese building materials industry. Energy Build. 84: 268-276

[49] Wang H, Chen Y, Chan C W H and Qin J 2011 A robust fault detection and diagnosis strategy for pressure-independent VAV terminals of real office buildings. Energy Build. 43: 1774-1783

[50] Shamshirband S, Khoshnevisan B, Yousefi M, Bolandnazar E, Anuar NB, Wahab A W A and Khan S U R 2015 A multiobjective evolutionary algorithm for energy management of agricultural systems-A case study in Iran. Renew. Sustain. Energy Rev. 44: 457-465

[51] Mogale D G, Dolgui A, Kandhway R, Kumar S K and Tiwari M K 2017 A multi-period inventory transportation model for tactical planning of food grain supply chain. Comput. Indust. Eng. 110: 379-394

[52] Mogale D G, Kumar S K, García Márquez F P and Kumar M 2017 Bulk wheat transportation and storage problem of public distribution system. Comput. Indust. Eng. 104: 80-97

[53] Banos R, Manzano-Agugliaro F, Montoya F G, Gil V, Alcayde A and Gomez J 2011 Optimization methods applied to renewable and sustainable energy: a review. Renew. Sustain. Energy Rev. 15: 1753-1766

[54] Maiyar L M and Thakkar J J 2017 A combined tactical and operational deterministic food grain transportation model: particle swarm based optimization approach. Comput. Indust. Eng. 110: 30-42
[55] Mendes G, Ioakimidis C and Ferrão P 2011 On the planning and analysis of Integrated Community Energy Systems: a review and survey of available tools. Renew. Sustain. Energy Rev. 15: 4836-4854

[56] De A, Kumar S K, Gunasekaran A and Tiwari M K 2017 Sustainable maritime inventory routing problem with time window constraints. Eng.Appl. Artif. Intellig. 61: 77-95

[57] Fong K F, Hanby F I and Chow T T 2006 HVAC system optimization for energy management by evolutionary programming. Energy Build. 38: 220-231

[58] Ene S, Küçükoğlu İ, Aksoy A and Öztürk N 2016 A genetic algorithm for minimizing energy consumption in warehouses. Energy 114: 973-980

[59] Elsied M, Oukaour A, Youssef T, Gualous H and Mohammed O 2016 An advanced real time energy management system for microgrids. Energy 114: 742-752

[60] Ruiz G R, Bandera C F, Temes T G A and Gutierrez A S O 2016 Genetic algorithm for building envelope calibration. Appl. Energy 168: 691-705

[61] Paulo P, Branco F, de Brito J and Silva A 2016 Buildings Life - The use of genetic algorithms for maintenance plan optimization. J. Cleaner Prod. 121: 84-98

[62] Benet CH, Kassler A and Zola E 2016 Predicting expected TCP throughput using genetic algorithm. Comput. Netw. 108: 307-322

[63] Ashnani M H M, Johari A, Hashim H and Hasani E 2014 A source of renewable energy in Malaysia, why biodiesel? Renew. Sustain. Energy Rev. 35: 244-257

[64] Halder P K, Paul N and Beg M R A 2014 Assessment of biomass energy resources and related technologies practice in Bangladesh. Renew. Sustain. Energy Rev. 39: 444-460

[65] Chadwick D T, Mc Donnell K P, Brennan L P and Fagan C C 2014 Evaluation of infrared techniques for the assessment of biomass and biofuel quality parameters and conversion technology processes: a review. Renew. Sustain. Energy Rev. 30: 672-681

[66] Valero A and Valero A 2012 What are the clean reserves of fossil fuels? Resour. Conserv. Recycl. 68: 126-131

[67] Popp J, Lakner Z, Harangi-Rákos M and Fári M 2014 The effect of bio energy expansion: food, energy, and environment. Renew. Sustain. Energy Rev. 32: 559-578

[68] General Directorate of Renewable Energy 2014 Energy management principle for industry. Republic of Turkey Ministry of Energy and Natural Resources, Volume I, Fourth Revision, Ankara, Turkey

[69] Official of Turkish Sugar Factory Incorporeal. Available from: http://www.turkseker.gov.tr/, Access date: 12/02/2015. [in Turkish]

[70] International Energy Agency 2014 Energy Prices and Taxes. Issue 4, Fourth Quarter

[71] Valero A and Cuadra C S 2006 Thermoeconomic analysis, exergy, energy system analysis and optimization. Volume II, Oxford: EOLSS Publishers 1-30. Available from: www.eolss.net, Access date: 03/01/2015

[72] Kim D J 2010 A new thermoeconomic methodology for energy systems. Energy 35: 410-422

[73] Karaali R and Özturk I T 2015 Thermoeconomic optimization of gas turbine cogeneration plants. Energy 80: 474-485

[74] Republic of Turkey Ministry of Energy and Natural Resources, The Energy Productivity Legislation numbered 5627. Official Gazette Number 26510: Official Gazette, Date 
2007. Available from: www.enerji.gov.tr/en-US/Legislations. Access date: 15/02/2015 [in Turkish]

[75] Republic of Turkey Official Gazette, Increase of Efficiency Regulations About Energy Sources and Use of Energy.
Official Gazette Number 27035: Official Gazette, Date 2008. Available from: www.resmigazete.gov.tr, Access date: 15/02/2015 [in Turkish] 